\title{
REPERTOÁR STREDOVEKÉHO OFÍCIA NOTOVANÝCH FRAGMENTOV ŠTÁTNEHO ARCHÍVU TRENČÍN
}

\author{
Mgr. Veronika Garajová \\ Ústav hudobnej vedy SAV, Dúbravská cesta 9, 84104 Karlova Ves, e-mail: veronika. \\ garajova@savba.sk; http://cantus.sk
}

\section{Abstract}

Hundreds of fragmentary notated manuscripts have survived in the territory of Slovakia. Medieval fragments from the eleventh to the fifteenth centuries are deposited in several Slovak archives, libraries, and museums. One of the archives that houses a large number of notated fragments is the State Archives in Trenčín. During our music historical field research in this archive, we processed twenty-two notated medieval manuscripts in total. We analysed eleven fragments of antiphonaries, eight graduals, one missal, one breviary, and one fragment whose contents we did not manage to identify because it was severely damaged. Sixteen fragments are notated in Bohemian notation, which makes the State Archives in Trenčín the archive with the largest number of medieval fragments with this system of notation. This study aims for an indepth musical and liturgical analysis of the medieval office repertoire recorded in the fragments, identified in an interdisciplinary codicological palaeographic and music-palaeographic research to have belonged to a single liturgical codex which has unfortunately not survived in its entirety.

Keywords: Middle Ages, medieval, Trenčín, antiphonary, office, cantus planus, plainchant

\section{Úvod}

Notované fragmenty Štátneho archívu Trenčín môžeme datovat’ do 14. - 16. storočia. ${ }^{1}$ Zachované zlomky tvoria v súčasnosti zväčša obaly mestských úradných kníh

1 V roku 2009 spracovala muzikologička Eva Veselovská v rámci terénneho výskumu v Štátnom archíve Trenčín 22 stredovekých notovaných fragmentov. Základný opis prameňov bol publikovaný v dvoch štúdiách. VESELOVSKÁ, Eva: Bohemian Notation in the Medieval Slovakia. In: 
mesta Trenčín z rokov 1596 - 1662. Čast’ z rukopisov sa nachádza v samostatnej škatuli rôznych hudobnín z 15. až 20. storočia pod názvom Zbierka hudobnín rozličnej proveniencie (d’alej ZH-A). Všetky zachované materiály obsahujú hudobné dedičstvo jednohlasného liturgického spevu, tzv. gregoriánskeho chorálu (lat. cantus planus). Viaceré otázky o vzniku, pôvode a používaní týchto rukopisov sme nedokázali úplne objasnit’. Torzovitý stav nám stažil úplne presné stanovenie vedecko-výskumných záverov. V rámci výzdobného systému fragmentov absentujú zložitejšie iluminácie. Tento fakt skomplikoval presnejšie datovanie skúmaných materiálov na základe analýzy výzdoby. Z toho dôvodu nám pri presnejšom datovaní fragmentov bola nápomocná skôr analýza písma a uplatnenie postupov latinskej paleografie. Významným činitelom pri stanovení možnej proveniencie alebo vzniku a používania rukopisu bola hudobná a liturgická analýza.

Pri vyhodnocovaní hudobného repertoáru jednotlivých zlomkov sme využívali viaceré zdroje, $\mathrm{v}$ prvom rade národnú ${ }^{2}$ a medzinárodné databázy stredovekých hudobných rukopisov, ${ }^{3}$ dalej pramenné edície ${ }^{4}$ a monografie ${ }^{5}$ relevantných komparatívnych

Hudební věda, roč. 49, 2012, č. 4, s. 337-376; VESELOVSKÁ, Eva: Die böhmische Notation in der Slowakei im 14. und 15. Jahrhundert. In: HULKOVÁ, Marta (ed.): Musicologica Istropolitana VI. Bratislava : Stimul, 2007, s. 9-57. Komplexne bola táto skupina fragmentov analyzovaná a vyhodnotená v roku 2020 ako VI. zväzok edície Catalogus fragmentorum cum notis musicis medii aevi. GARAJOVÁ, Veronika: Catalogus fragmentorum cum notis musicis medii aevi e civitate Trenchini. Ed. Catalogus fragmentorum cum notis musicis medii aevi in Slovacia. Tomus VI. Bratislava : Ústav hudobnej vedy Slovenskej akadémie vied, 2020.

2 Národná databáza stredovekých rukopisov a fragmentov z územia Slovenska - Cantus Planus in Slovacia: Slovak Early Music Database (SEMD; http://cantus.sk/) sprístupňuje k dnešnému dňu 15 kompletných stredovekých rukopisov a 369 fragmentárne zachovaných stredovekých rukopisov. Rovnako sú v rámci databázy SEMD sprístupnené aj výsledky výskumov stredovekých fragmentov zo Štátneho archívu Trenčín (http://cantus.sk/archive/50).

3 Pri výskume notovaných stredovekých fragmentov z Trenčína sme využívali najmä databázu Cantus Index ktorá v rámci svojej siete ku dnešnému dňu združuje 13 samostatných národných a univerzitných databáz (http://cantusindex.org/). Nenahraditelné pri výskume boli aj knižničné a archívne databázy Manuscriptorium a Monasterium, sprístupňujúce české stredoveké notované pramene (http://www.manuscriptorium.com/en) a stredoveké notované kódexy z Klosterneuburgu (http://www.monasterium.net/).

4 Pri vyhodnocovaní fragmentárne zachovaných zlomkov sme využívali najmä edície mad’arských hudobných historikov Corpus Antiphonalium Officii - Ecclesiarum Centralis Europae (CAO - ECE), Melodiarum Hungariae Medii Aevi, Monumenta Monodica Medii Aevii, Antiphonae a Responsories a Musicalia Danubiana.

5 SOPKO, Július - BURAN, Dušan - VESELOVSKÁ, Eva: Bratislavský antifonár I. Martin : Slovenská národná knižnica, 2004; SOPKO, Július - JANKOVIČ, Lubomír - BURAN, Dušan: Bratislavský antifonár II. Martin : Slovenská národná knižnica, 2000; BURAN, Dušan: Bratislavský antifonár III. Martin : Slovenská národná knižnica, 2005; BURAN, Dušan: Bratislavský antifonár V. Martin : Slovenská národná knižnica, 2007; SZENDREI, Janka: Breviarium notatum Strigoniense: saeculi XIII. Budapest : Magyar Tudományos Akadémia Zenetudományi Intézet, 1998; SZENDREI, Janka: Graduale Strigoniense s. XV/XVI. Budapest : MTA Zenetudományi Intézet, 1990; SZENDREI, Janka - RYBARIČ, Richard: Missale Notatum Strigoniense ante 1341 in Posonio. Budapest : MTA Zenetudományi Intézet, 1982; SOPKO, Július: Nitriansky kódex. Martin : Matica slovenská, 1987; ADAMKO, Rastislav - VESELOVSKÁ, Eva - ŠEDIVÝ, Juraj: Spišský antifonár. Antiphonale Scepusiense. Ružomberok : Katolícka univerzita v Ružomberku, 2008; AKIMJAK, Amantius - ADAMKO, Rastislav - BEDNÁRIKOVÁ, Janka: Spišský graduál Juraja z Kežmarku z roku 1426. Ružomberok: PF KU v Ružomberku, 2006. 
materiálov. ${ }^{6} \mathrm{Na}$ základe analýzy notačného systému, porovnania zhodných kodikologicko-paleografických parametrov a vyhodnotenia liturgického obsahu sme spomedzi skúmaných trenčianskych materiálov určili dve skupiny zlomkov, ktoré vykazujú jednotné charakteristické znaky. Ide o 16 fragmentov, ktoré sú notované českou notáciou. Tieto zlomky môžeme na základe ich liturgického obsahu rozdelit do dvoch základných skupín. Skupina „A“ označuje fragmenty notované českou notáciou, ktoré sú fragmentmi antifonára. Skupina "G“ označuje fragmenty notované českou notáciou, ktoré pochádzajú z graduálu. Prvá skupina nám približuje hudobný repertoár liturgických spevov stredovekého ofícia a druhá skupina obsahuje omšové nápevy. Skúmané fragmenty tvoria vrchný obal mestských úradných kníh mesta Trenčín z rokov 1601 $1662 .{ }^{7} \mathrm{~V}$ rámci štúdie sa budeme podrobnejšie venovat analýze hudobno-liturgického obsahu skupiny „A“, konkrétne podskupiny „A1“. Do skupiny „A“ radíme fragmenty so signatúrami $M M T N-K n / I-11$, Mestský protokol 1601; MMTN - Kn/I - 12, Mestský protokol 1602 - 1603; MMTN - Kn/I - 13, Mestský protokol 1604; MMTN - Kn/I - 14, Mestský protokol 1605 - 1606; MMTN - Kn/I - 15, Mestský protokol 1607 1608; MMTN - Kn/I - 16, Mestský protokol 1609 - 1610; MMTN - Kn/I - 17, Mestský protokol 1613; MMTN - Kn/I - 18, Mestský protokol 1614 - 1615; MMTN - Kn/I - 27, Mestský protokol 1630; a MMTN - Kn/I-32, Mestský protokol $1661-1664 .^{8}$

$\mathrm{V}$ rámci skupiny „A“ bola pri kodikologicko-paleografickej a hudobno-paleografickej analýze identifikovaná podskupina fragmentov „A1“, ktorá preukazuje zhodné parametre. Od ostatných fragmentov skupiny „A“ sa fragmenty skupiny „A1“ odlišovali najmä pisárskou rukou, rozmermi notovej osnovy, rozmermi zrkadla a neumových znakov, najmä punktu. U všetkých zlomkov skupiny „A1“ boli tieto parametre totožné. Na základe uvedených poznatkov môžeme konštatovat', že zlomky $M M T N$ - Kn/I - 11; MMTN - Kn/I - 12, Mestský protokol 1602 - 1603; MMTN - Kn/I - 13, Mestský protokol 1604; MMTN - Kn/I - 15, Mestský protokol 1607 - 1608; MMTN - Kn/I - 18, Mestský protokol 1614 - 1615 a MMTN - Kn/I - 27, Mestský protokol 1630 boli v minulosti súčastou jedného liturgického kódexu. Nález vy̌šieho počtu fragmentov v jednej inštitúcii, ktoré pochádzajú z rovnakého liturgického kódexu, je na Slovensku pomerne vzácny. $Z$ toho dôvodu budeme týmto zlomkom venovat špeciálnu pozornost’ a $\mathrm{v}$ rámci štúdie sa budeme zaoberat' hudobno-paleografickou

6 Napriek obrovskému nárastu zdigitalizovaných a online dostupných prameňov nám však stále absentovali niektoré dôležité údaje potrebné pre komparáciu prameňov strednej Európy.

7 Použitie väčšieho množstva zlomkov z jedného alebo z dvoch nepoužívaných liturgických kódexov v jednej archívnej, muzeálnej alebo knižničnej inštitúcii je na Slovensku pomerne vzácny. Podobnú situáciu dokumentujú pramene v štátnych archívoch v Banskej Bystrici, v Banskej Štiavnici a v Kremnici. VESELOVSKÁ, Eva: Najstaršie hudobné pramene Banskej Bystrice. In: BÁRDIOVÁ, Marianna (ed.): Banská Bystrica: historicko-etnologické štúdie. 2. Osobnosti v dejinách mesta. Banská Bystrica : Univerzita Mateja Bela, 2001, s. 79-90. VESELOVSKÁ, Eva: Catalogus fragmentorum cum notis musicis medii aevi e civitate Schemnitziensi. Bratislava : Ústav hudobnej vedy Slovenskej akadémie vied, 2011.

8 Najvýznamnejšími fondmi Štátneho archívu Trenčín sú Magistrát mesta Trenčín a Magistrát mesta Prievidza. Práve v rámci fondu Magistrát mesta Trenčín (dalej len MMTN) bolo objavených 17 pergamenových notovaných fragmentov z časového obdobia od konca 14. až do prvej polovice 16. storočia. Šestnást fragmentov je notovaných českou notáciou, ktorá je v skúmanom pramennom materiáli zastúpená $\mathrm{v}$ najväčšom počte. 
a hĺbkovou hudobno-liturgickou analýzou repertoáru stredovekého ofícia fragmentov podskupiny „A1“.

\section{Historické predpoklady vzniku notovaných fragmentov}

Viaceré otázky vzniku a používania stredovekých rukopisov, ktoré sa zachovali v Štátnom archíve $\mathrm{v}$ Trenčíne, sa pokúsime zodpovedat’ i na základe analýzy historických predpokladov, ktoré súvisia so skriptorskou činnostou v danom regióne. Opierajúc sa o štúdiu Juraja Šedivého ${ }^{9}$ môžeme konštatovat, že poznáme len velmi málo kódexov, ktoré sa dajú spájat’ s územím stredovekého Považia (ich vznik alebo používanie v tejto geografickej oblasti Slovenska). Tento prekvapivý fakt je o to zarážajúcejší, ak si uvedomíme, kol'ko možných uchovávatel’ov, resp. producentov písomnej kultúry v danom regióne pôsobilo. Ako oporný bod pre šírenie knižnej kultúry na tomto území berieme rozvoj a stabilizáciu krest’anstva na Považí, ako aj v blízkom okolí. Počiatky krestanstva v tomto geografickom priestore kladieme približne na koniec 8. storočia. Neskôr, za vlády kniežat’a Pribinu, vzniklo v Nitre pri kostolíku, ktorý vysvätil sol’nohradský biskup Adalrám okolo roku 828, misijné centrum. Existenciu misijných centier v rámci Vel'kej Moravy dokazujú archeologické nálezy, aj písomné pramene. ${ }^{10} \mathrm{~S}$ rozvojom krestanstva na tomto území súviselo i slúženie prvých bohoslužieb, pri ktorých spočiatku používali najmä importované kódexy.

Výraznejšia zmena prichádza za vlády prvého uhorského krála Štefana I. Ten svojimi reformami cirkevnej organizácie vytvoril základnú štruktúru arcidiecéz, diecéz a vel'kofár. Rovnako nariadil, aby liturgické knihy v strediskových kostoloch (kostoly pre viacero dedín) zabezpečil biskup. ${ }^{11} \mathrm{~V}$ období včasného stredoveku na Považí existovalo niekolko pomerne rovnomerne rozmiestnených cirkevných centier. Práve pri týchto centrách existuje odôvodnený predpoklad vlastníctva, resp. domácich odpisov liturgických kódexov. Na Hornom Považí medzi ne patrila napríklad lokalita Liptovská Mara. ${ }^{12}$ Kostol pochádza z 12. (možno už 11.) storočia a prislúchajúca farnost’ bola sídlom liptovskej časti hontianskeho vicearchidiakonátu. ${ }^{13}$

Pri kristianizácii našej krajiny zohrali v úvodnej fáze šírenia viery najvýznamnejšiu úlohu benediktíni. Na územie Považia (do Nového Mesta nad Váhom) poslal benediktínov pravdepodobne král Štefan I. Benediktíni sem mohli príst’ najskôr okolo roku 1015. Po Štefanovej smrti na tomto území prevládali rozsiahle mocenské boje medzi nemeckou, českou a uhorskou stranou. Nepokojné obdobie pretrvávalo až do roku 1096, ked' vojaci prvej križiackej výpravy vyplienili celé územie Považia. Za týchto okolností sa benediktíni presunuli na bezpečnejšie miesto, na spomínanú Skalku pri

9 ŠEDIVÝ, Juraj: Podmienky pre rozvoj knižnej kultúry na stredovekom Považí. In: DOMOVÁ, Miroslava (ed.) Kniha 2001 - 2002. Martin : SNK, 2002, s. 229-237.

10 KUČERA, Matúš: Slovenské dejiny I. Od príchodu Slovanov do roku 1526. Bratislava : Literárne informačné centrum, 2011, s. 90-91.

11 GYÖRFFY, György: Wirtschaft und Gesellschaft der Ungarn um die Jahrtausendwende. Budapest : Akadémiai Kiadó, 1983, s. 275.

12 ULIČNÝ, Ferdinand: Vývin historického osídlenia v zatopenej časti Liptova do konca 16. storočia. In: HRUŠOVSKÁ, Marta (ed.): Ochrana pamiatok 12. Bratislava : Obzor, 1987, 45-47.

13 ŠEDIVÝ, Ref. 9, s. 230. 
Trenčíne. ${ }^{14}$ Do Nového Mesta nad Váhom sa vrátili na podnet krála Bela IV., ktorý im dal do daru mariánsky kostol. Benediktíni sa snažili zúročit’ skutočnost’, že mariánsky kostol zohral významnú úlohu počas tatárskych vojen a dali mu charakter pútnického miesta. Počas 13. storočia však svoju konjunktúru prežívalo aj zakladanie súkromných kláštorov, ktoré slúžili šlachticom zväčša ako rodové pohrebisko. Vel'kej oblube sa tešil rád už spomínaných benediktínov - benediktínskych bola viac ako polovica z 90 súkromných kláštorov Uhorska. ${ }^{15}$ Podobná situácia bola aj na území dnešného Slovenska. Za vlády Žigmunda Luxemburského na území Slovenska existovalo 52 kláštorov. Z toho $25 \%$ bolo benediktínskych kláštorov, 17,3 \% františkánskych a 11,5 \% bolo paulínskych a premonštrátskych kláštorov. Tesne za nimi boli kláštory augustiniánov, mníchov pustovníkov a dominikánov. Ostatné rády - cisterciti, kartuziáni, karmeliti boli zastúpené len nepatrne. ${ }^{16}$

Aj Stibor zo Stiboríc dal v Novom Meste nad Váhom vybudovat jeden z takýchto súkromných kláštorov ako miesto svojho odpočinku. Išlo o kláštor augustiniánov kanonikov (Ordo canonicorum Regularium S. Augustini). Tento rád však nebol totožný s augustiniánskymi mníchmi pustovníkmi (Eremitae Ordinis S. Augustini). Na území Slovenska neexistoval $\mathrm{v}$ tej dobe ani jeden takýto kláštor augustiniánskych mníchov pustovníkov. ${ }^{17}$ V roku 1414 vydal Stibor zakladajúcu listinu kláštora. Po smrti Stibora prebral iniciatívu nad augustiniánskou prepozitúrou prvý prior Peter, ktorý hlavne kvôli svojim kontaktom v Čechách vytvoril kompletnú kapitulu s dvanástimi augustiniánskymi reholníkmi z kláštora v Šternbergu a v Prahe na Karlove. Po prieniku protestantizmu sa väčšina kanonikov vrátila na Moravu a kláštor zanikol. ${ }^{18}$

Ďalšie významné miesto na Považí spojené s benediktínmi je benediktínske opátstvo Skalka pri Trenčíne a jeho okolie, ktoré má dlhú krest’anskú tradíciu. Jeho počiatky môžeme hladat' už v prvej polovici 11. storočia, ked' na tomto mieste pôsobili sv. Svorad (Andrej) a Benedikt. Opátstvo založil pravdepodobne nitriansky biskup Jakub už pred rokom 1208. ${ }^{19}$ Posledný opát sa spomína v roku 1527. Kláštor zanikol rok na to, hoci záujem o jeho obnovenie pretrvával aj neskôr. ${ }^{20} \mathrm{~V}$ roku 1644 Skalku odovzdal

14 GÁBRIŠ, Július: Dejiny prepozitúry Panny Márie v Novom Meste nad Váhom. Bratislava : Obzor, 1969, s. 10-15.

15 KRISTÓ, Gyula - ENGEL, Pál - MAKK, Ferenc: Korai magyar történeti lexikon: 9-14. század. Budapest : Akadémiai Kiadó, 1994, s. 490; DVOŘÁKOVÁ, Daniela: Rytier a jeho král. Stibor zo Stiboríc a Žigmund Luxemburský. Budmerice : Rak, 2003, s. 335.

16 Údaje sme čerpali z knihy DVOǨÁKOVÁ, Ref. 15, s. 335. Autorka čerpala údaje z práce madarskej historičky ROMHÁNYI, Beatrix F.: Kolostorok és társaskáptalanok a középkori Magyarországon [Monasteries and Collegiate Chapters in Medieval Hungary]. Budapest: Arcanum [online]. Budapest : Arcanum, 2008, 166 s. Skutočný počet kláštorov na území dnešného Slovenska mohol byt' o niečo vyšší. Obe autorky pracovali len s kláštormi, ktoré boli spomenuté v písomných prameňoch.

17 DVOŘÁKOVÁ, Ref. 15, s. 335.

18 GÁBRIŠ, Ref. 14, s. 52.

19 KUZMÍK, Jozef: Knižné zbierky a knižnice na Slovensku v stredoveku a renesancii. Martin : Matica slovenská, 1990; Richard Marsina vo svojej štúdii MARSINA, Richard: Stredoveká hudobná pamiatka zo Skalky. In: Adoremus, roč. 3, 1996, č. 2, s. 13, predpokladá vznik opátstva v roku 1224.

20 ROMHÁNYI, Beatrix: Kolostorok és társaskáptalanok a középkori Magyarországon [Monasteries and Collegiate Chapters in Medieval Hungary]. Budapest : Arcanum, 2008, s. 65. 
nitriansky biskup Ján Püsky jezuitom, ktorí tu pôsobili až do svojho zrušenia v roku 1773. Na dolnom Považí bol kláštor na Skalke najvýraznejším cirkevno-kultúrnym centrom. Dôvodom môže byt’ silný vplyv nitrianskej kapituly a biskupa, resp. zoborského kláštora.

Jediný doteraz známy primárny dôkaz stredovekej hudobnej kultúry z Považia pochádza práve zo Skalky pri Trenčíne. Mimoriadne zaujímavý fragment antifonára našiel v Mad’arskom krajinskom archíve ${ }^{21}$ Richard Marsina. ${ }^{22}$ Fragment je taktiež notovaný českou notáciou a bol použitý ako vrchná väzba urbára majetkov opátstva Skalka. Išlo o antifonár, ktorý sa mohol používat priamo v kláštore. Obsah zachytáva uhorské ofícium k sv. Svoradovi-Andrejovi a sv. Benediktovi Sanctissimi viri Andreas. Predpokladáme, že aj zlomok zo Skalky môže byt' súčastou rovnakej skupiny antifonára ako fragmenty z Trenčína. Použitý je totožný notačný systém, ktorý dokladá kontaktné notové písmo (česká a kvadratická notácia) z okolia olomouckého skriptória. ${ }^{23}$ Ofícium sv. Svorada-Andreja a Benedikta však jasne určuje ostrihomskú liturgickú tradíciu. Význam fragmentu zo Skalky spočíva najmä v dochovaní ofícia, ktoré sa spája priamo s územím dnešného Slovenska, resp. s ostrihomskou liturgickou tradíciou.

Pravdepodobne najstarším rukopisom, ktorý zachytáva ofícium sv. Svorada-Andreja a Benedikta je Ostrihomský breviár zo Záhrebu, ktorý našiel pred nedávnom v Metropolitnej knižnici arcidiecézy v Záhrebe (Metropolitanska knjižnica Zagrebačke nadbiskupije) Gábriel Szoliva. ${ }^{24}$ Zlomok z Budapešti však každopádne korešponduje so zachovaným pramenným materiálom zo ŠA v Trenčíne.

\section{Hudobnopaleografická charakteristika skupiny „A1“}

Textové zrkadlo fragmentov antifonára skupiny „A1“25 je ohraničené červeným dvojitým orámovaním. Počet sústav na jednom fóliu je 12. Použitá je štvorlinajková červená notová osnova. Custos je písaný v tvare kvadry. Klúč f nachádzame v dvoch tvaroch. Bud'v podobe gotizovanej virgy bez hlavice s dvoma o terciu nižšie postavenými rombusmi, alebo $\mathrm{v}$ podobe písmena f. Klúč c sa používa v klasickom tvare písmena c. Notácia používa posuvku b. Celkový duktus písma je jasne naklonený doprava, čo je typický znak pre klasický systém českej notácie. Notácia bola zrejme dopisovaná až po napísaní textu, čoho dôkazom sú prekryvy neum a textu, hlavne spodných neu-

${ }_{21}$ HU MNL OL E 152 - Reg. Coll. Tren. - Fasc. 7. - No. 73.

22 MARSINA, Ref. 19, s. 13-14.

23 ČERVENKA, Stanislav: Středověké chorální rukopisy moravských a slezských sbírek a jejich muzikologická exploatace - současný stav a prespektivy. In: BUREŠOVÁ, Alena (ed.): Kritické edice hudebních památek. Olomouc: Univerzita Palackého v Olomouci, 1996, s. 39-44.

24 SZOLIVA, Gábriel: Secunda pars breviarii: - A 13. századi esztergomi breviárium kottás szanktoráléjának rekonstrukciója felé. In: Magyar Könyvszemle, roč. 135, 2019, č. 3, s. 307-330. Pozri tiež: SZENDREI, Janka: In basilica sancti Emmerami. András és Benedek históriája. In: Magyar Zene, roč. 37, 1998, s. 21-28.

25 Hudobno-paleografická analýza stredovekých rukopisov z Trenčína, ktorá zahŕňa aj hudobno-paleografickú analýzu skupiny „A“: GARAJOVÁ, Veronika: Hudobno-paleografická analýza stredovekých rukopisov z Trenčína. In: Muzikologické fórum, roč. 7, 2018, č. 2, s. 53-71. 
mových znakov a horných dížok písmen, ktoré vznikli tým, že pisár nenechal dostatok priestoru pre melodický zápis neumových znakov. Gotizácia tvarov jednotlivých neumových znakov je $\mathrm{v}$ pokročilom štádiu. $\mathrm{Z}$ jednotónových neum sa dominantne využiva punktum. Podobne ako v iných notovaných stredovekých fragmentoch z územia Slovenska, ani tu sa samostatná virga takmer nevyskytuje. Virga sa využíva iba ako súčast viactónových neumových štruktúr (pes, climacus, scandicus a porrectus). Dvojtónová neuma pes je naklonená do pravej strany a tvoria ju dva vertikálne umiestnené rombické punkty, spojené zvyčajne tenkým vlasovým tahom. V niektorých častiach fragmentov nachádzame pes v modifikovanej verzii, ktorá vznikla pod vplyvom kvadratickej notácie. Vrchné punktum nemá tvar rombický, ale štvorcový (ako v kvadratickej notácii). Clivis je pravouhlý, s rombickým zakončením. Trojtónové neumy torculus a porrectus sa svojím tvarom taktiež približujú notácii kvadratickej. Climacus je vo väčšine prípadov vytvorený z troch samostatných klesajúcich punktov s duktom doprava. Doprava naklonený scandicus pozostáva z dvojtónovej neumy pes a punktu.

V rámci komparácie jednotlivých neumových tvarov zlomkov zo Štátneho archívu Trenčín sme sledovali podobnost's fragmentom HU MNL OL E 152, No. 73 zo Skalky a vybranými kódexmi českej a moravskej proveniencie: rukopismi Knihovny Metropolitní kapituly svatého Václava (Olomouc) - CO 6 Antiphonarium, CO 7 Antiphonarium $;{ }^{26}$ rukopismi Moravského zemského archívu v Brne ${ }^{27}$ Graduál FM 2, ${ }^{28}$ Antifonár $F M 5^{29}$ a Bratislavským antifonárom $V .^{30}$

Pri komparácii sme sa zamerali najmä na neumové znaky custos, scandicus, climacus, torculus a klúče. Neumové znaky fragmentov skupiny „A“ sa najviac približujú notácii Bratislavského antifonára $V$ (fragmenty $M M T N$ - Kn/I-14 a MMTN - Kn/I-28) a notácii Antifonára FM 5 (fragmenty MMTN - Kn/I-16 a MMTN Kn/I-17). Notácia zlomkov skupiny „A1“ sa najviac približuje notácii Antifonára FM 5 a zlomkom Olomouckého antifonára z knižnice Vlastivedného múzea v Olomouci. $^{31}$

26 CO 6 Antiphonarium, CO 7 Antiphonarium; Zemský archiv Opava, pobočka Olomouc, knihovna Metropolitní kapituly svatého Václava (Olomouc); BISTŘICKÝ, Jan - BOHÁČEK, Miroslav - ČÁDA, František: Seznam rukopisů metropolitní kapituly v Olomouci. Praha : Státní archiv v Opavě, 1961.

27 ZACHOVÁ, Irena - STANISLAV, Petr: Soupis sbírky rukopisů bývalého Františkova muzea v Brně. Brno : Masarykův ústav AV ČR, 2011.

28 Moravský zemský archiv, fond G 11, FM 2, Graduál.

29 Moravský zemský archiv, fond G 11, FM 5, Antifonár.

30 VESELOVSKÁ, Eva - ADAMKO, Rastislav - BEDNÁRIKOVÁ, Janka: Stredoveké pramene cirkevnej hudby na Slovensku. Bratislava : Ústav hudobnej vedy Slovenskej akadémie vied, 2017, s. 91-99.

31 ČERVENKA, Stanislav - HRBÁČOVÁ, Jana: Fragmenty středověkých liturgických kodexů v knihovně Vlastivědného muzea v Olomouci. In: Zprávy vlastivědného muzea v Olomouci, 2013, č. 306, s. 37-53. 
Tabulka neumových znakov

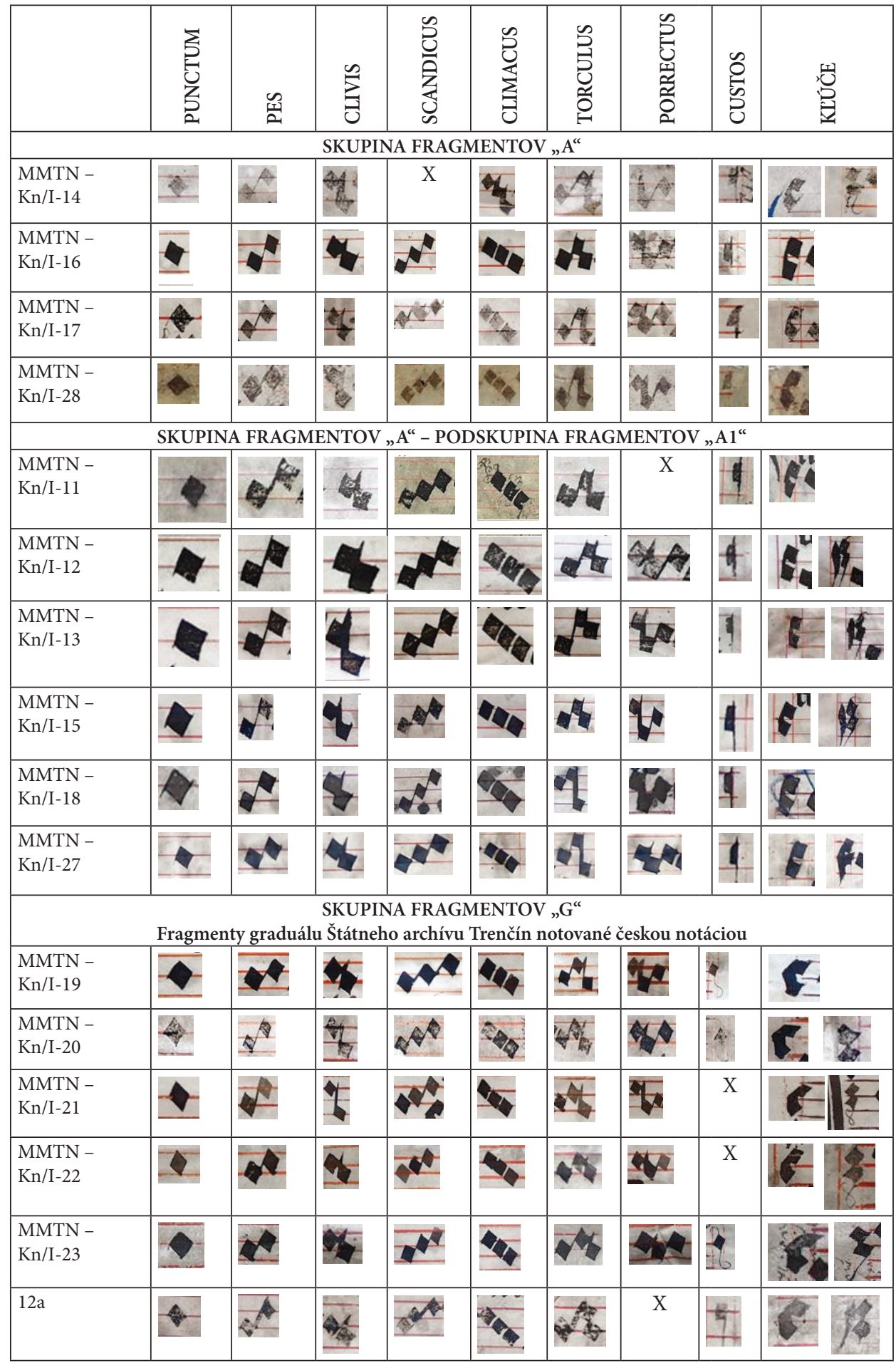




\begin{tabular}{|c|c|c|c|c|c|c|c|c|c|}
\hline & 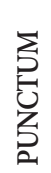 & 垉 & $\sum_{\mathcal{J}}^{\infty}$ & 总 & 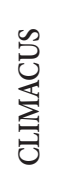 & 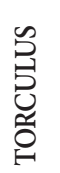 & 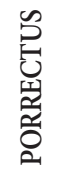 & 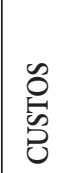 & 总 \\
\hline \multicolumn{10}{|c|}{ VZOROVÉ KÓDEXY A FRAGMENTY } \\
\hline \begin{tabular}{l|} 
Fragment zo \\
Skalky - HU \\
MNL OL E 152, \\
No. $73^{32}$
\end{tabular} & & & & $\mathrm{X}$ & & & $\mathrm{X}$ & & \\
\hline \begin{tabular}{l|}
$\mathrm{CO} 6$ \\
Antiphonarium $^{33}$
\end{tabular} & & & & & & 2 & $A$ & 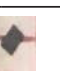 & \\
\hline $\begin{array}{l}\text { CO } 7 \\
\text { Antiphonarium }^{34}\end{array}$ & & & & & & & 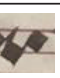 & $\checkmark$ & \\
\hline $\begin{array}{l}\text { FM } 2 \\
\text { Graduál }^{35}\end{array}$ & & & & $\mathrm{X}$ & & & & 4 & \\
\hline $\begin{array}{l}\text { FM } 5 \\
\text { Antifonár }{ }^{36}\end{array}$ & & & & & & & & $\Rightarrow$ & \\
\hline $\mathrm{BA} \mathrm{V}^{37}$ & & & & N & & & $A$ & lis & \\
\hline
\end{tabular}

\section{Porovnanie pisárskych rúk a notačných systémov skupiny „A“ a „A1“}

Rukopisy skupiny fragmentov „A“ a „A1“ dokumentujú gotickú minuskulu. Zlomky vykazujú znaky súdobých pisárskych rúk. V rámci skupiny „A“ je možné identifikovat’ viacero pisárskych rúk. Vo všeobecnosti je možné konštatovat', že oproti písmu fragmentov skupiny „A1“ je písmo skupiny fragmentov „A“ oblejších tvarov, menej kaligrafické a lámanie driekov nie je konzekventné. Písmo fragmentov skupiny „A1“ pôsobí monumentálne, je pravidelné, typicky vertikálne s dominanciou tieňových tahov a velkým počtom manieristických vlasových tahov. Písmo má potlačené horné aj dolné dížky.

32 MARSINA, Richard: Stredoveká hudobná pamiatka zo Skalky. In: Adoremus, roč. 3, 1996, č. 2, s. 13-14; Magyar Országos Levéltár / Magyar Nemzeti Levéltár HU MNL OL E 152 - Reg. Coll. Tren. - Fasc. 7. - No. 73.

33 CO 6 Antiphonarium, Zemský archiv Opava, pobočka Olomouc, knihovna Metropolitní kapituly svatého Václava (Olomouc); BISTŘICKÝ, Jan - BOHÁČEK, Miroslav - ČÁDA, František: Seznam rukopisů metropolitní kapituly v Olomouci. Praha : Státní archív v Opavě, 1961.

34 CO 7 Antiphonarium, Zemský archiv Opava, pobočka Olomouc, knihovna Metropolitní kapituly svatého Václava (Olomouc); BISTŘICKÝ, Jan - BOHÁČEK, Miroslav - ČÁDA, František: Seznam rukopisů metropolitní kapituly v Olomouci. Praha : Státní archív v Opavě, 1961.

35 Moravský zemský archiv, fond G 11, FM 2, Graduál.

36 Moravský zemský archiv, fond G 11, FM 5, Antifonár.

37 Bratislavský antifonár V, Slovenský národný archív SNA 17, Dostupné online: http://cantus.sk/ source/6775. 


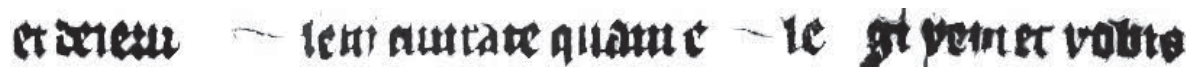

Obr. 1: Písmo skupiny antifonárov „A“ - Fragment antifonára MMTN - Kn/I-28, Protocollum Civitatis Trenchiniensis anni $1637-1642$

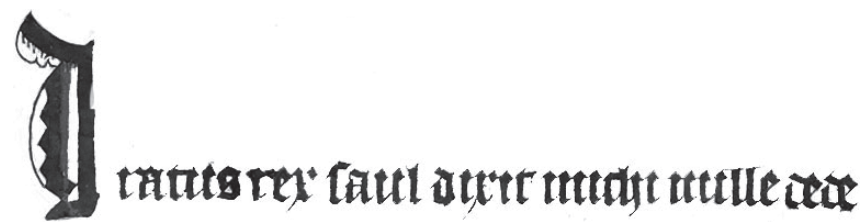

Obr. 2: Písmo skupiny antifonárov „A1“ - Fragment antifonára MMTN - Kn/I-18, Protocollum Civitatis Trenchiniensis anni 1614 - 1615

\section{Hudobný repertoár skupiny „A1“ (hudobno-liturgická analýza)}

Pomocou podrobnej analýzy a komparácie liturgie jednotlivých fragmentov bolo možné zistit predpokladanú liturgickú tradíciu, ktorú fragmenty dokumentujú. Špecifické znaky omšovej alebo ofíciovej liturgie dokážu vo všeobecnosti velmi presne poukázat’ na liturgickú alebo hudobnú prax daného regiónu, oblasti, mesta či kláštora. Viaceré striktné a jednotné pravidlá sa síce viažu na čast' spevov temporálu a sanktorálu omšovej i ofíciovej liturgie, ale aj napriek tomuto faktu dokumentujú lokálne liturgie (i v našom geografickom priestore) viaceré špecifiká konkrétnej lokality alebo objednávatela. V stredovekom Uhorsku sa stretáme najmä s ostrihomskou (prípadne so spišským, kalocsajským-záhrebským alebo sedmohradským variantom), s českou, pol'skou, salzburskou, pasovskou, akvilejskou alebo krakovskou liturgiou. ${ }^{38}$

Vzhladom na geografickú polohu mesta Trenčín, historické predpoklady (činnost’ augustiniánov v Novom Meste nad Váhom) a zachovanú prevažne českú notáciu frag-

38 CZAGÁNY, Zsuzsa: Corpus Antiphonalium Officii - Ecclesiarum Centralis Europae. III/A Praha (Temporale). Budapest : Zenetudományi Intézet, 1996; CZAGÁNY, Zsuzsa: Corpus Antiphonalium Officii - Ecclesiarum Centralis Europae. III/B Praha (Sanctorale, Commune Sanctorum). Budapest : MTA Zenetudományi Intézet, 2002; GILÁNYI, Gábriela - KOVÁCS, Andrea: Corpus Antiphonalium Officii - Ecclesiarum Centralis Europae. IV/A Aquleia (Temporale). Budapest: MTA Zenetudományi Intézet, 2002; DOBSAY, László: Corpus Antiphonalium Officii - Ecclesiarum Centralis Europae. V/A Esztergom/Strigonium (Temporale). Budapest : MTA Zenetudományi Intézet, 2004; KOVÁCS, Andrea: Corpus Antiphonalium Officii - Ecclesiarum Centralis Europae. V/B Esztergom/Strigonium (Sanctorale). Budapest : MTA Zenetudományi Intézet, 2006; KOVÁCS, Andrea: Corpus Antiphonalium Officii - Ecclesiarum Centralis Europae. VI/A Kalocsa-Zagreb (Temporale). Budapest : MTA Zenetudományi Intézet, 2008; KOVÁCS, Andrea: Corpus Antiphonalium Officii - Ecclesiarum Centralis Europae. VI/B Kalocsa-Zagreb (Sanctorale). Budapest : MTA Zenetudományi Intézet, 2008; KOVÂCS, Andrea: Corpus Antiphonalium Officii - Ecclesiarum Centralis Europae. VII/A Transylvania - Varád (Temporale). Budapest : MTA Zenetudományi Intézet, 2008; KOVÁCS, Andrea: Corpus Antiphonalium Officii - Ecclesiarum Centralis Europae. VII/B Transylvania - Varád (Sanctorale). Budapest : MTA Zenetudományi Intézet, 2008. 
mentov existoval odôvodnený predpoklad, že zachovaná liturgická tradícia sa bude približovat' bud' k ostrihomskej, alebo najmä susednej, pražskej liturgickej tradícii. Na základe daného predpokladu sme obsah fragmentov antifonára pre overenie hypotézy porovnali s viacerými liturgickými tradíciami, a to s ostrihomskou (variant paulínsky a spišský), pražskou, salzburskou, a najmä s liturgickou tradíciou kódexov augustiniánskeho kláštora Klosterneuburg (Rakúsko). Hudobný obsah a verzie spevov sme porovnali najmä s tzv. reprezentatívnymi rukopismi bratislavskej kapituly (Bratislavský antifonár I, IIa a IIb, Bratislavský antifonár III a Bratislavský antifonár IV), ${ }^{39}$ ktoré reprezentujú ostrihomskú liturgickú i hudobnú tradíciu a taktiež s online prístupnými rukopismi (najmä klosterneuburské antifonáre). ${ }^{40}$

\section{MMTN - Kn/I-11}

Fragment antifonára $M M T N$ - Kn/I-11 obsahuje šest’ spevov cezročného obdobia („per annum“) z tzv. Histórie králov (Historia de regum). Na zlomku je zachovaných šest’ antifón na Magnifikat. V rámci výberových antifón na vešpery z tejto časti liturgického roka ide pravdepodobne o v poradí štvrtú až deviatu antifónu. Kompletné sú spevy Iratus rex Saul (003411) a Quis enim in (004546). Spevy Obsecro Domine (004099) a Rex autem David (004650) sú neúplné. Začiatky a konce d’alších spevov boli súčastou predchádzajúcich alebo nasledujúcich fólií kódexu. V rámci liturgickej analýzy fragmentu nebola zistená úplná zhoda so žiadnym porovnávaným liturgickým poriadkom. ${ }^{41} \mathrm{~V}$ prípade $M M T N$ - Kn/I-11 sa ako najpríbuznejší porovnávaný rukopis javí A-KN 1012 (Antiphonale Klosterneuburg, Augustiner-Chorherrenstift - Bibliothek, 1012), ${ }^{42} \mathrm{v}$ ktorom sa objavujú všetky spevy antifón z predmetného fragmentu. Radenie antifón sa však nezhoduje. Ďalšie dva porovnávané liturgické poriadky, pražský a ostrihomský, sa líšili výberom i poradím antifón. V rôznych stredoeurópskych tradíciách sa odlišoval i počet výberových antifón. Pražský rítus ob-

39 DOBSAY, László - SZENDREI, Janka: Antiphonen (Antiphonen im 1. Modus). Londýn; New York; Praha : Bärenreiter Kassel, 1999; DOBSAY, László - SZENDREI, Janka: Antiphonen (Antiphonen im 2. bis 6. Modus). Londýn; New York; Praha : Bärenreiter Kassel, 1999; DOBSAY, László - SZENDREI, Janka: Antiphonen (Antiphonen im 7. und 8. Modus). Londýn; New York; Praha : Bärenreiter Kassel, 1999; DOBSZAY, László - SZENDREI, Janka: Responsories. Modes 1-3. Budapest : Balassi Kiadó, 2013. Rukopisy sú dostupné aj online v databáze Slovak Early Music Database - Cantus Planus in Slovacia (http://cantus.sk/).

40 Antiphonary A-KN 1011, Augustiner-Chorherrenstift - Klosterneuburg, Cod. 1011 - dostupné online: http://cantus.uwaterloo.ca/index? source=123654; Antiphonary A-KN 1012, Augustiner-Chorherrenstift - Klosterneuburg, Cod. 1012 - dostupné online: http://cantus.uwaterloo.ca/ index? source=123613; Antiphonary A-KN 1015, Augustiner-Chorherrenstift - Klosterneuburg, Cod. 1015 - dostupné online: http://cantus.uwaterloo.ca/index?source=123655; Antiphonary A-KN 1017, Augustiner-Chorherrenstift - Klosterneuburg, Cod. 1017 - dostupné online: http:// cantus.uwaterloo.ca/index? source $=123615$

${ }^{41}$ Zlomok sme porovnali s pražským liturgickým poriadkom a ostrihomským liturgickým poriadkom. CZAGÂNY, Zsuzsa: Corpus Antiphonalium Officii - Ecclesiarum Centralis Europae. III/A Praha (Temporale). Budapest : Zenetudományi Intézet, 1996; DOBSAY, László: Corpus Antiphonalium Officii - Ecclesiarum Centralis Europae. V/A Esztergom/Strigonium (Temporale). Budapest : MTA Zenetudományi Intézet, 2004.

42 http://cantus.uwaterloo.ca/index? source $=123613$. 
sahuje v ideálnom prípade 10 antifón, ostrihomský 9 antifón. Liturgický poriadok kódexu A-KN 1012 obsahuje až 13 antifón. Prvý spev Nonne iste est David (003948) sa v rámci troch vybraných a porovnávaných liturgií nachádza vo všetkých tradíciách. Iratus rex Saul (003411) sa v pražskom ani ostrihomskom liturgickom poriadku medzi antifónami Am1 - Am10 nevyskytuje vôbec. ${ }^{43}$ Túto antifónu nenachádzame ani v iných častiach ofícia Histórie králov. V prípade $A-K N 1012$ sa objavuje tento spev na mieste v poradí šiestej výberovej antifóny. Spev Quis enim in omnibus sicut David (004546) sa podobne ako predchádzajúca antifóna Nonne iste est David v rámci liturgického poriadku pražského a ostrihomského rítu nenachádza. V kódexe $A-K N 1012$ sa antifóna Quis enim in omnibus sicut David vyskytuje na pozícii piatej antifóny. Pozície týchto dvoch spevov sú teda na $M M T N$ - Kn/I-11 radené opačne. Antifóna Obsecro Domine (004099) sa v liturgickom poriadku pražského rítu vôbec nevyskytuje. $\mathrm{V}$ ostrihomskom liturgickom poriadku je umiestnená zhodne na siedmej pozícii. V kódexe A-KN 1012 sa Obsecro Domine spieva ako jedenásta antifóna. Nasledujúce antifóny MMTN - Kn/I-11 Rex autem David (004650) a Doleo super te (002321) sa nachádzajú vo všetkých porovnávaných liturgických poriadkoch. V pražskom ríte je siedmou antifónou Rex autem David (004650), v Ostrihome sa táto antifóna uvádza ako šiesta v poradí. V prípade A-KN 1012 je ôsma. Ďalší spev Doleo super te (002321) nachádzame v pražskom liturgickom poriadku na mieste šiestej antifóny. V Ostrihome je piata a v A-KN 1012 siedma. Z melodického hladiska sme zo všetkých 6 spevov mohli porovnat' len 2 úplné spevy Iratus rex Saul, Quis enim in a čast’ neúplného spevu Obsecro Domine.

Antifónu Iratus rex Saul (003411), ktorú v publikácii Monumenta Monodica Medii $A_{e v i}{ }^{44}$ (d’alej len MMMA) nachádzame pod číslom 8265, môžeme melodicky zaradit’ do skupiny antifón ôsmeho modu. ${ }^{45}$ Antifóna patrí do skupiny antifón D2. ${ }^{46}$ Táto skupina antifón je charakteristická svojím tretím melodickým úsekom, ktorý často ostáva na tóne $d$ a končí sa ozdobnou kadenciou. Varianty melódií možno pozorovat’ aj v spôsobe, akým sú v posledných dvoch slabikách rozdelené melizmy. Štvrtý úsek sa v tomto podtype vždy opiera o kostru melodického vzorca $a-c^{1}-g$. Melódia spevu Iratus rex Saul je totožná s melódiou vzorového rukopisu OFM - $119^{47}$ (Antiphonarium Ordinis Fratrum Minorum). Diferencia na konci spevu zodpovedá vzoru $c-c-h-c-a-g$. Druhý kompletný spev Quis enim in (004546) je v prvom mode (MMMA 1224). Skupina „C“, do ktorej je antifóna zaradená, je charakteristická priamym spojením medzi tónmi $d$ a $a$. Toto spojenie sa najčastejšie vyskytuje vo forme ligatúry, ktorej v niektorých prípadoch predchádza tón $c$, alebo spojenie $c-f{ }^{48}$ Melódia antifóny sa od publikovanej verzie v MMMA líši iba v mieste sicut David. Melódia fragmentu: si-cut Da-vid je a-f

43 A1 Loquere Domine; A2 Cognoverunt omnes a Dan, A3 Praevaluit David.

44 DOBSAY - SZENDREI, Antiphonen, Ref. 39.

45 DOBSAY - SZENDREI, Antiphonen, Ref. 39, s. 1150.

46 DOBSAY - SZENDREI, Antiphonen, Ref. 39, s. 107.

47 OFM-119: Antiphonarium Ordinis Fratrum Minorum. Temporale, Pars Aestivalis, 14. storočie. Budapest, Egyetemi Könyvtar (Bibl. Universitatis), Cod. lat. 119, kvadratická notácia. 128 ff. Radó Nr. 178. Mezey Nr. 119. Szendrei C48.

48 DOBSAY - SZENDREI, Antiphonen, Ref. 39, s. 49. 
$f-g-f$, melódia vzorových fragmentov: $g-f g-a-g$. Melódia diferencie antifón notovaných $\mathrm{v}$ prvom mode sa zhoduje s variantom $1 \mathrm{~d} 1 \mathrm{a}-a-g-f-g-a-g-f-e-d$.

Neúplná antifóna Rex autem David (004650) (MMMA 8508) patrí do skupiny antifón $\mathrm{v}$ ôsmom mode s diferenciou $c-c-h-c-a-g$. Zachovaná čast' spevu má melódiu takmer totožnú s melódiou vzorových rukopisov: Bratislavského antifonára I (STR-3) ${ }^{49}$ a OFM-119 Antiphonarium Ordinis Fratrum Minorum. Drobná melodická odlišnost’ sa vyskytuje na mieste: fi-li mi(2). Melódia fragmentu: $d-g g f-e$ $-d$-c, melódia vzorového kódexu: podatus $d$-a a $g$-f-e-d. Rovnako malá melodická odchýlka sa nachádza v slove Absonolon. Melódia zlomku sa skladá z torculu c-f-e, $f-g-f$ a punktu $g$. Melódia vzorového kódexu je $d-f-e, f-g-f g$. Ostatné časti spevu sú totožné s melódiou fragmentu.

Tabulka č. 1: $M M T N-\mathrm{Kn} / \mathrm{I}-11$, Historia de regum

\begin{tabular}{|l|l|l|l|l|}
\hline & $\begin{array}{l}\text { MMTN - Kn/I-11, } \\
\text { Historia de regum }\end{array}$ & Pražský rítus & Ostrihomský rítus & $\begin{array}{l}\text { Klosterneuburg, } \\
\text { A-KN 1012 }\end{array}$ \\
\hline Am4 & $\begin{array}{l}\text { Nonne iste est David, } \\
003948\end{array}$ & Nonne iste est David & Nonne iste est David & $\begin{array}{l}\text { Nonne iste est David } \\
\text { de }\end{array}$ \\
\hline Am5 & $\begin{array}{l}\text { Iratus rex Saul, } \\
003411\end{array}$ & Mons Gelboe & Doleo super te & $\begin{array}{l}\text { Quis enim in } \\
\text { omnibus sicut }\end{array}$ \\
\hline Am6 & Quis enim in, 004546 & Doleo super te & Rex autem cooperto & $\begin{array}{l}\text { Iratus rex Saul dixit } \\
\text { mihi }\end{array}$ \\
\hline Am7 & $\begin{array}{l}\text { Obsecro Domine, } \\
004099\end{array}$ & Rex autem David & Obsecro Domine & $\begin{array}{l}\text { Doleo super te frater } \\
\text { mi }\end{array}$ \\
\hline Am8 & $\begin{array}{l}\text { Rex autem David, } \\
004650\end{array}$ & $\begin{array}{l}\text { Dixit autem David } \\
\text { ad Do- }\end{array}$ & Unxerunt Salomonem & $\begin{array}{l}\text { Rex autem David } \\
\text { cooperto capite }\end{array}$ \\
\hline Am9 & $\begin{array}{l}\text { Doleo super te, } \\
002321\end{array}$ & Unxerunt Salomonem & Clamabat Elizeus & $\begin{array}{l}\text { Saul et Jonathas } \\
\text { amabiles et }\end{array}$ \\
\hline Am10 & X & Clamabat Elizeus & X & $\begin{array}{l}\text { Dixitque David ad } \\
\text { dominum cum }\end{array}$ \\
\hline Am11 & X & X & X & $\begin{array}{l}\text { Obsecro domine } \\
\text { aufer iniquitatem } \\
\text { servi }\end{array}$ \\
\hline Am12 & X & X & X & $\begin{array}{l}\text { Unxerunt Salomonem } \\
\text { Sadoc sacerdos et }\end{array}$ \\
\hline Am13 & X & $\begin{array}{l}\text { Xlamabat Eliseus ad } \\
\text { Eliam pater }\end{array}$ \\
\hline
\end{tabular}

49 STR-3: Antiphonarium Strigoniense: Bratislavský antifonár I EC Lad. 3, Štátny archív v Bratislave, okolo roku 1430 (olim: Knauz 3). 237 ff., métsko-gotická notácia. Dostupné online: http://cantus. sk/source/14828; VESELOVSKÁ - ADAMKO - BEDNÁRIKOVÁ, Ref. 30, s. 60-64. 


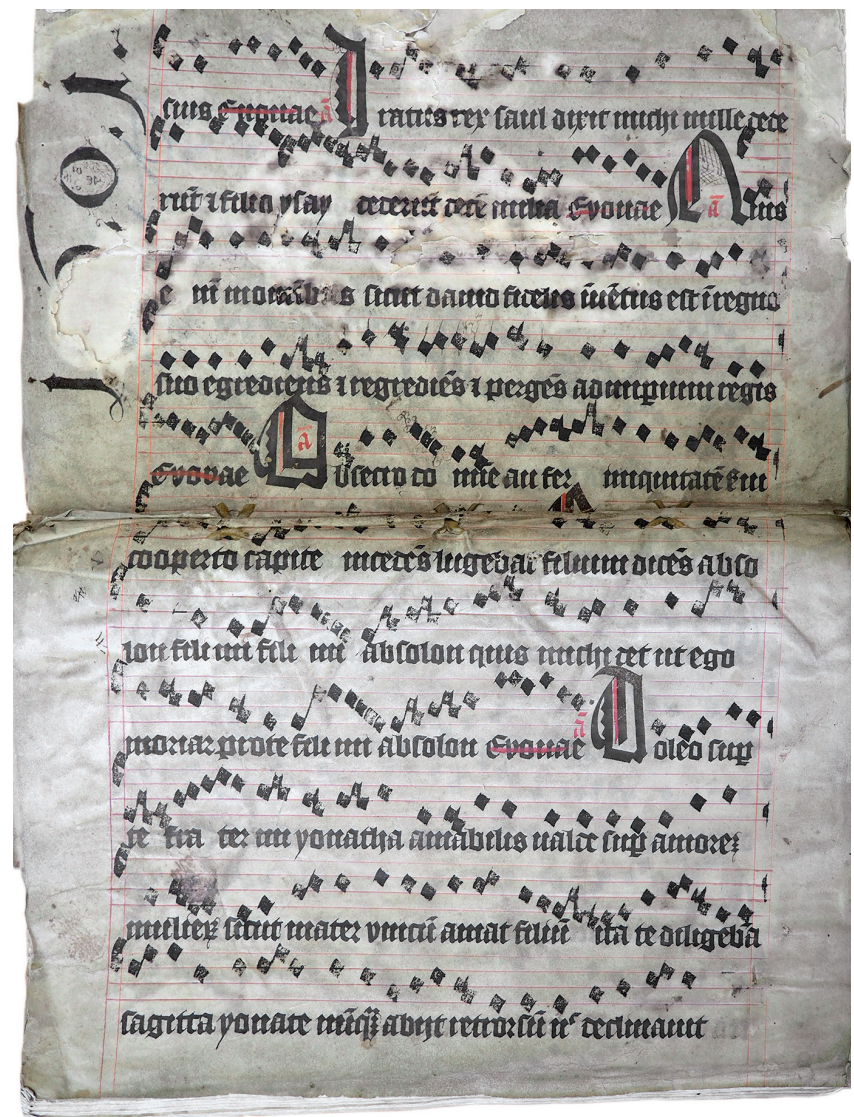

Obr. 3: Antifonár SK-TN MMTN-Kn/I-11, Štátny archív Trenčín

\section{MMTN - Kn/I-12}

Fragment antifonára MMTN - Kn/I-12 dochováva celkovo 13 spevov obdobia cez rok - „per annum“, tzv. Histórie múdrosti (Historia Sapientiae). Z obsahového hladiska je v rámci zlomku zachovaných 7 veršov a 6 responzórií spievaných počas nóny (pravdepodobne ide o siedmy až trinásty verš a ôsme až trináste responzórium). Kompletne je zachovaných 6 spevov Magna enim sunt judicia (007113), Deduxisti sicut oves (007113a), Deum time et mandata (006416), Ne derelinquas me Domine (007204), Apprehene Domine arma (007204a), Praebe fili cor tum (007416). Spevy Ne forte satiatus (007841a), Super salutem et omnem (007727), Dixi sapientiae (007727a), Timentibus Deum (006416a), Quae sunt in corde (007457), Imperfectum meum (007457a) a Attende fili mi (007416a) sú neúplné. Pri obsahovej analýze - podobne ako v predchádzajúcom prípade - nebola zistená úplná zhoda so žiadnym ideálnym porovnávaným liturgickým poriadkom - pražským ani ostrihomským. Najväčšiu príbuznost' vykazuje liturgický poriadok A-KN 1012 a pražský liturgický poriadok. Je však nutné konšta- 
tovat, že odlišnost' sa neobjavuje len v poradí daných spevov, ale aj v ich celkovom počte. Poradie prvých troch spevov Ne forte satiatus, Magna enim sunt judicia, Deduxisti sicut oves je zhodné vo všetkých porovnaných poriadkoch. Rozdielne poradie responzórií a veršov v porovnaní s pražským a ostrihomským rítom je zrejmé až od spevu č́slo 4 - responzória Super salutem et omnem. Poradie spevov Super salutem et omnem (007727) a príslušného verša Dixi sapientiae Cantus (007727a) sa zhoduje práve s poradím spevov v $A-K N$ 1012. V pražskom liturgickom poriadku sa toto responzórium a verš nachádza ako desiate responzórium $\mathrm{v}$ poradí a desiaty verš $\mathrm{v}$ poradí. V prípade ostrihomského rítu je to dvanáste responzórium a dvanásty verš. Spev č. 5 a 6 - responzórium Deum time et mandata (006416) a príslušný verš Timentibus Deum (006416a) - sa v pražskom ani v ostrihomskom liturgickom poriadku v rámci responzórií a veršov spievaných počas nóny Historie sapientiae nevyskytuje vôbec. Dané spevy figurujú v A-KN 1012. Nezhoduje sa však poradie. V antifonári A-KN 1012 sa tieto spevy spievajú ako pätnáste v poradí.

Responzórium Ne derelinquas me Domine (007204) a verš Apprehende Domine arma (007204a) sa svojím radením nezhodujú ani s jedným porovnávaným poriadkom. $\mathrm{V}$ pražskom a ostrihomskom ríte nachádzame predmetné responzórium ako deviate. V A-KN 1012 je uvedené ako desiate. Poradie predposlednej dvojice spevov Quae sunt in corde (007457) a Imperfectum meum (007457a) sa poradím nezhoduje so žiadnym z uvedených liturgických poriadkov. Pražský rítus a A-KN 1012 uvádzajú responzórium Quae sunt ako jedenáste, ostrihomský rítus ako deviate. Posledná dvojica spevov Praebe fili cor tuum (007416) a Attende fili mi (007416a) sa v pražskom liturgickom poriadku a v A-KN 1012 uvádzajú na dvanástom mieste, $\mathrm{v}$ ostrihomskom na jedenástom. Z melodického hladiska je možné porovnat 7 kompletných spevov. Responzórium Magna enim sunt judicia (007113) s veršom Deduxisti sicut oves (007113a) patrí do skupiny responzórií tretieho modu (v publikácii Lászlóa Dobszaya a Janky Szendrei Responsories. Modes 1-3, č. 3024 dalej len Responsories)..$^{50}$ Prvý melodický úsek responzória je pravidelný, upevnený dlhším motívom, ktorý sa drží melodického vzorca, využívaného aj v spevoch 7 . modu (c-acd-c). Fráza $d f$-g-a $g$ (magnificasti) zvyčajne naznačuje začiatok druhého melodického úseku, strednej časti spevu. $V$ tomto prípade sa však na tomto mieste začína tretí melodický úsek, v ktorom melodická línia kadencuje na $e$ namiesto $d$.

Melódia fragmentu v princípe kopíruje melódiu vzorového kódexu, Bratislavského antifonára $I$ (dalej $B A I$ ). Mierne odchýlky sú badatelné najmä v melizmatických častiach druhej a tretej časti spevu. Najvýraznejšie rozdiely sú v časti populum tuum et honorasti. Melódia fragmentu je bohatšia ako melódia Bratislavského antifonára I, čo odráža pomer jednoduchých a viactónových neum. Melódia fragmentu: Po-pu-lum tu-um: fac-c-hca ca.hchag-aage.f..$^{51}$

Melódia vzorového BA I: Po-pu-lum tu-um: $f c-c-c$ ca.ahchag-agfe.e. Podobná situácia je aj v prípade príslušného verša Deduxisti sicut oves, ktorého melódia kopíruje melódiu BA I. Malé melodické odchýlky sú najmä v časti Deduxisti sicut. Kompozícia neum ostáva rovnaká ako v prípade vzorového kódexu, rovnako frázovanie. Melódia

DOBSZAY, László - SZENDREI, Janka: Responsories. Modes 1-3, Ref. 39, s. 726.

${ }^{51}$ Zistené diferencie $\mathrm{v}$ rámci spevov sú oproti porovnávaným prameňom vyznačené $\mathrm{v}$ texte boldom. 
fragmentu: De-du-xi-sti si-cut c-c-cdc-ahchag h-a. Melódia BA I: De-du-xi-sti si-cut c$-c$-cdc-ahcag c-c.

Ďalším zachovaným spevom $M M T N$ - Kn/I-12 je responzórium Deum time et mandata (006416). Daný spev sa v publikácii Responsories nevyskytuje. Responzórium je v druhom mode. V kódexe A-KN 1012 sa nachádza na pozícii č. 15. V prvom melodickom úseku melódia fragmentu kopíruje melódiu spevu A-KN 1012. Malé rozdiely nachádzame najmä v prvom úseku Deum time me et, kde je melódia fragmentu v porovnaní s melódiou kódexu o niečo jednoduchšia. V slove de-um melódia pozostáva $\mathrm{z}$ dvoch punktov $d$-c. V prípade melódie $A-K N 1012$ je melódia zložená z punctu a porrectu $d$ - $c d$. Zásadnejší rozdiel v melódii je badatel'ný v slove me. Melódia fragmentu je o vel'kú sekundu vyššie: clivis e-d, ako melódia $A-K N 1012$ - clivis $d$-c. V prípade druhého úseku spevu - Hoc est omnis homo je rozdiel medzi melodickými líniami zjavnejší. Ide o pomerne výrazné melizmatické úseky, v ktorých melódia vo fragmente nekorešponduje ani s melódiou $A-K N$ 1012, ani so žiadnym iným rukopisom z databázy Cantus Index. Melodický záver spevu je zhodný v oboch prípadoch. Melódia fragmentu: hoc est om-ni ho-mo: gagffgahaga a agfefgefd-da cd-d. Melódia A-KN 1012 hoc est om-ni ho-mo: $c d f d f e f d c d d$ ddcacdfdfefd-dh cd-d.

Melódia spevu Ne derelinquas me (007204 Responsories, č. 4055) je zaujímavá z niekol'kých ohladov. Úvodná čast' spevu Ne derlinquas me Domine Pater je písaná v c-klúči, ktorý sa nachádza na tretej linajke, čo spôsobilo, že melódia je oproti vzorovému kódexu $B A I$ transponovaná o kvintu vyššie. Domnievame sa však, že v tomto prípade išlo len o chybu pisára, pretože ostatná čast’ spevu je notovaná v c-klúči, ktorý sa nachádza na 4. linajke. Náš predpoklad o chybe pisára potvrdzuje aj fakt, že v takomto prípade by melódia kopírovala melódiu vzorového kódexu ovela vernejšie, než v prípade transpozície takého krátkeho melodického úseku. Zvyšné časti responzória sú melodicky zhodné s melódiou vzorového kódexu. Odchýlky sú badatelné len vo výraznejších melizmatických častiach, napríklad v slove me-o-rum. Melódia fragmentu je čiastočne pozmenená a neumová kompozícia mierne zjednodušená. Skladá sa $\mathrm{z}$ dvoch torculov a clivisu. Melódia spevu patrí k spevom štvrtého modu. Melódia fragmentu: me-o-rum f-dcdede-fd. Melódia vzorového kódexu: me-o-rum f-dccdede-ed.

Melodický charakter príslušného verša Apprehende arma (007204 Responsories, č. 4055) sa vel’mi podobá responzóriu, ku ktorému prislúcha. Spev patrí do zoznamu spevov štvrtého modu. Zásadnejšia melodická zmena je zjavná v súvislosti s odlišnostou textu verša vo fragmente a porovnávaných zdrojoch. Text fragmentu: Apprehende domine arma et scutum et exsurge in adjutorium mihi. Text vzorového kódexu: Apprehende arma et scutum et exsurge in adjutorium mihi. Melódia textu, ktorý je zhodný $\mathrm{v}$ oboch prameňoch, je takmer totožná. Malý rozdiel nachádzame pri poslednej slabike slova Apprehende. Melódia slabiky de má značne melizmatický charakter. Zmena je v poslednej pasáži melizmy, ked’ sa melódia príslušnej slabiky de $M M T N-K n / I-12$ končí torculom, a nie klesajúcim tónovým radom.

Melódia fragmentu: Ap-pre-hen-de: a-a-a-gffgagagefe. Melódia vzorového kódexu: Ap-pre-hen-de: a-a-a-gffgagagef.

Praebe fili (007416 Responsories, č. 1066) je posledným kompletne zachovaným spevom fragmentu $M M T N$ - Kn/I-12. Melódia fragmentu verne kopíruje melódiu 
vzorového kódexu - Bratislavského antifonára III (Str-1). ${ }^{52}$ Spev patrí k spevom prvého modu. Kompozičná stránka neum fragmentu je v priebehu celého spevu totožná so vzorovým fragmentom. Melodicky sa fragment od vzorového kódexu líši len v melódii slabiky tur slova ad-da-tur, kde má melódia fragmentu opačný melodický sled ako melódia vzorového kódexu. Melódia fragmentu: a-acac-gagf. Melódia vzorového kódexu: a-acac-afga.

Tabul'ka č. 2: MMTN - Kn/I-12, Historia Sapientiae

\begin{tabular}{|c|c|c|c|c|}
\hline & $\begin{array}{l}\text { MMTN - Kn/I-12, } \\
\text { Historia Sapientiae }\end{array}$ & Pražský rítus & $\begin{array}{l}\text { Ostrihomský } \\
\text { rítus }\end{array}$ & $\begin{array}{l}\text { Klosterneuburg, A-KN } \\
1012\end{array}$ \\
\hline V7 & $\begin{array}{l}\text { Ne forte satiatus, } \\
\text { 007841a }\end{array}$ & Ne forte satiatus & Ne forte satiatus & $\begin{array}{l}\text { Ne forte satiatus evomam } \\
\text { illud }\end{array}$ \\
\hline R8 & \begin{tabular}{|l}
$\begin{array}{l}\text { Magna enim sunt } \\
\text { judicia, } 007113\end{array}$ \\
\end{tabular} & $\begin{array}{l}\text { Magna enim sunt } \\
\text { judicia }\end{array}$ & $\begin{array}{l}\text { Magna enim sunt } \\
\text { judicia }\end{array}$ & $\begin{array}{l}\text { Magna enim sunt judicia } \\
\text { tua }\end{array}$ \\
\hline V8 & \begin{tabular}{|l} 
Deduxisti sicut oves, \\
007113a
\end{tabular} & \begin{tabular}{|l|}
$\begin{array}{l}\text { Deduxisti sicut } \\
\text { oves }\end{array}$ \\
\end{tabular} & \begin{tabular}{|l|}
$\begin{array}{l}\text { Deduxisti sicut } \\
\text { oves }\end{array}$ \\
\end{tabular} & $\begin{array}{l}\text { Deduxisti sicut oves } \\
\text { populum tuum }\end{array}$ \\
\hline R9 & $\begin{array}{l}\text { Super salutem et } \\
\text { omnem, } 007727\end{array}$ & \begin{tabular}{|l} 
Ne derelinquas \\
me Domine
\end{tabular} & \begin{tabular}{|l} 
Ne derelinquas \\
me Domine \\
\end{tabular} & $\begin{array}{l}\text { Super salutem et omnem } \\
\text { pulchritudinem }\end{array}$ \\
\hline V9 & Dixi sapientiae, 007727a & Apprehende arma & Apprehende arma & Dixi sapientiae soror mea es \\
\hline R10 & $\begin{array}{l}\text { Deum time et mandata, } \\
006416\end{array}$ & \begin{tabular}{|l|}
$\begin{array}{l}\text { Super salutem et } \\
\text { omnem }\end{array}$ \\
\end{tabular} & $\begin{array}{l}\text { Quae sunt in } \\
\text { corde }\end{array}$ & $\begin{array}{l}\text { Ne derelinquas me domine } \\
\text { pater }\end{array}$ \\
\hline V10 & $\begin{array}{l}\text { Timentibus Deum, } \\
\text { 006416a }\end{array}$ & Dixi sapientiae & $\begin{array}{l}\text { Imperfectum } \\
\text { meum }\end{array}$ & $\begin{array}{l}\text { Apprehende arma et } \\
\text { scutum et }\end{array}$ \\
\hline R11 & \begin{tabular}{|l} 
Ne derelinquas me \\
Domine, 007204
\end{tabular} & \begin{tabular}{|l|} 
Quae sunt in \\
corde
\end{tabular} & Praebe fili cor & $\begin{array}{l}\text { Quae sunt in corde } \\
\text { hominum }\end{array}$ \\
\hline V11 & $\begin{array}{l}\text { Apprehende Domine } \\
\text { arma, 007204a }\end{array}$ & \begin{tabular}{|l|}
$\begin{array}{l}\text { Imperfectum } \\
\text { meum }\end{array}$ \\
\end{tabular} & Attende fili mi & $\begin{array}{l}\text { Imperfectum meum } \\
\text { viderunt oculi tui }\end{array}$ \\
\hline R12 & $\begin{array}{l}\text { Quae sunt in corde, } \\
007457\end{array}$ & Praebe fili cor & \begin{tabular}{|l|}
$\begin{array}{l}\text { Super salutem et } \\
\text { omnem }\end{array}$ \\
\end{tabular} & Praebe fili cor tuum mihi \\
\hline V12 & \begin{tabular}{|l} 
Imperfectum meum, \\
007457a
\end{tabular} & Attende fili mi & Dixi sapientiae & $\begin{array}{l}\text { Attende fili mi sapientiam } \\
\text { meam }\end{array}$ \\
\hline R13 & \begin{tabular}{|l} 
Praebe fili cor tuum, \\
007416
\end{tabular} & $\mathrm{X}$ & $\mathrm{X}$ & $\begin{array}{l}\text { Audi fili mi disciplinam } \\
\text { patris }\end{array}$ \\
\hline V13 & $\begin{array}{l}\text { Attende fili mi, } \\
\text { 007416a }\end{array}$ & $\mathrm{X}$ & $\mathrm{X}$ & $\begin{array}{l}\text { Honora dominum de tua } \\
\text { substantia }\end{array}$ \\
\hline & $\mathrm{X}$ & $\mathrm{X}$ & $\mathrm{X}$ & $\begin{array}{l}\text { Aversio parvulorum } \\
\text { interficiet eos et }\end{array}$ \\
\hline & $\mathrm{X}$ & $\mathrm{X}$ & $\mathrm{X}$ & $\mathrm{O}$ viri ad vos clamito \\
\hline & $\mathrm{X}$ & $\mathrm{X}$ & $\mathrm{X}$ & Deum time et mandata ejus \\
\hline & $\mathrm{X}$ & $\mathrm{X}$ & $\mathrm{X}$ & $\begin{array}{l}\text { Timentibus deum nihil } \\
\text { deest et }\end{array}$ \\
\hline
\end{tabular}

52 Bratislavský antifonár III (Antiphonary of Bratislava III), EC Lad. 6, Štátny archív v Bratislave, 161 ff, Métsko-gotická zmiešaná notácia. SOPKO, Július: Stredoveké kódexy slovenskej provenience 1. Stredoveké latinské kódexy v slovenských knižniciach. Martin : Matica slovenská, 1981, č. 7; KNAUZ, Nándor: A pozsonyi káptalannak kéziratai - Codices manuscripti capituli Posoniensis. Budapest : Nyomatott Horák Egyed betüivel, 1870; SZENDREI, Janka: A magyar középkor hangjegyes forrásai. Budapest : MTA Zenetudományi Intézet, 1981. 


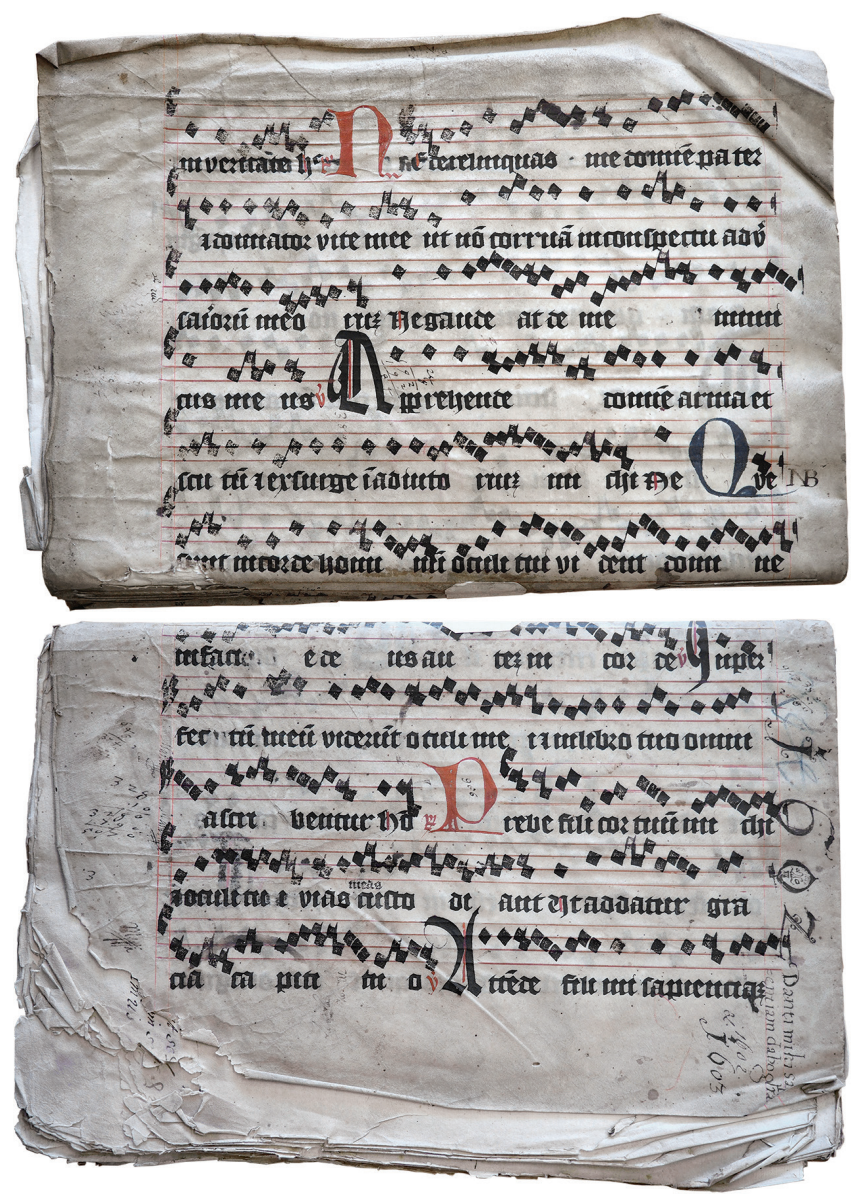

Obr. 4: Antifonár SK-TN MMTN-Kn/I-12, f.1v, Štátny archív Trenčín

\section{MMTN - Kn/I-13}

Tretí fragment antifonára $M M T N$ - Kn/I-13 použitý ako väzba mestského protokolu Protocollum Civitatis Trenchiniensis anni 1602 - 1603 obsahovo predchádza predošlý fragment $M M T N-K n / I-12$. Na fóliu sa zachovalo spolu 11 spevov. Pravdepodobne ide o responzóriá a $\mathrm{k}$ nim prislúchajúce verše, ktoré v rámci kódexu boli na tretom až siedmom mieste príslušného sviatku daného liturgického poriadku. Kompletná melódia a text sa však dochovali len v prípade 4 spevov - Domine Pater et Deus (006387a), Gyrum caeli circuivi (006793), Ego in altissimis (006793a), Verbum iniquum (007841).

Poradie spevov a obsahová stránka fragmentov sú v porovnaní s pražskou a ostrihomskou ideálnou tradíciou úplne totožné. Malý rozdiel je badatelný pri porovnaní liturgického poriadku $A-K N$ 1012. Tretie responzórium spolu s tretím veršom a štvrtým responzóriom má oproti fragmentu zamenené poradie. Pora- 


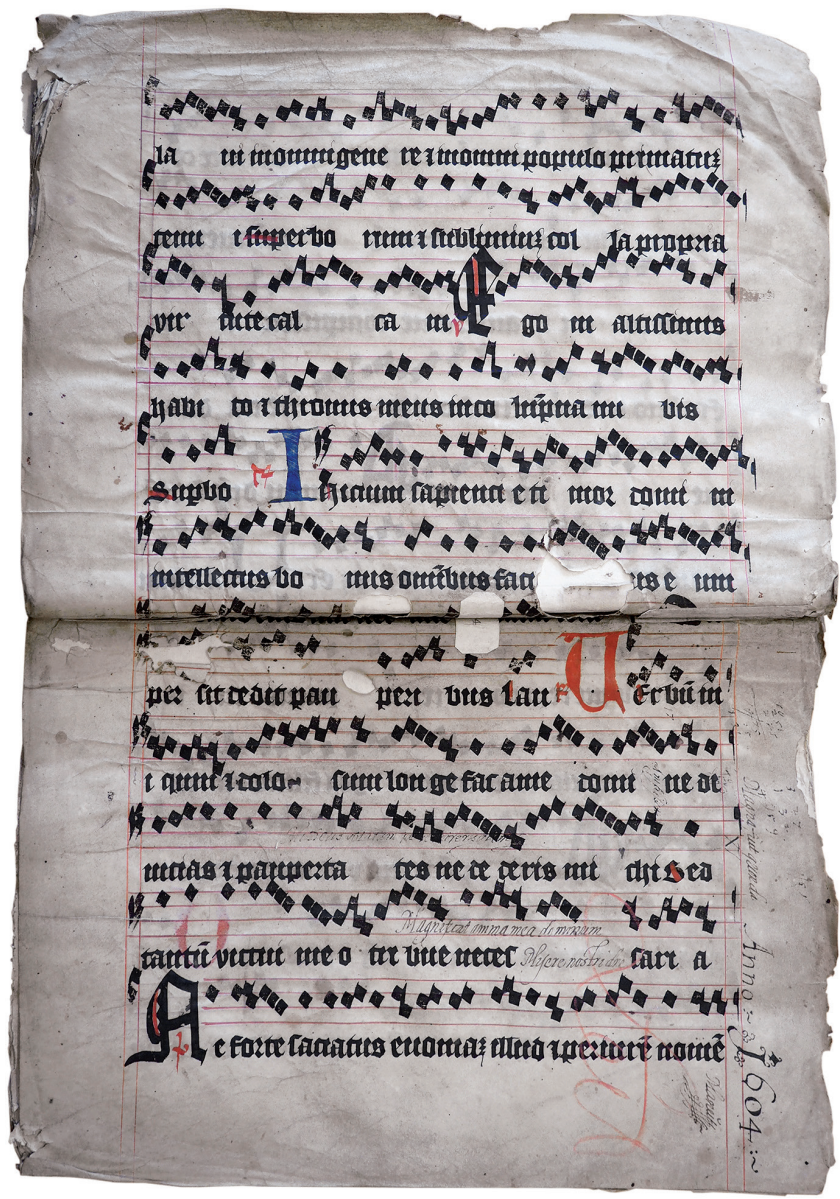

Obr. 5: Antifonár SK-TN MMTN-Kn/I-13, f.1v, Štátny archív Trenčín

die ostatných spevov je podobne ako pri predchádzajúcich liturgických tradíciách zhodné. Verš Domine pater et Deus (006503 Responsories, č. 1098) sa melodicky výrazne nelíši od vzorového kódexu $B A I$. Spev patrí medzi spevy prvého modu. Podobne ako v predchádzajúcich spevoch je odchýlka melódie fragmentu od vzorového kódexu viditelná najmä v melizmatickej časti záveru spevu - v slove maligno. Pozmenené je okrem melódie aj frázovanie a kompozičná stránka zápisu melódie. Melódia fragmentu pracuje s frázovaním ma-lig-no, kde najväčšia melizma pripadá na slabiku ma. Melódia slabiky lig klesá štvortónovým radom nadol a fráza je zakončená podatom $g a$ a clivisom $g f$. Melódia vzorového kódexu pracuje s frázovaním ma-li-gno. Melizmatické časti pripadajúce na prvú a druhú slabiku slova sú porovnatelné dlhé. Melizma slabiky li je však o poznanie dlhšia a rozvinutejšia ako $\mathrm{v}$ prípade melódie fragmentu. Fráza je zakončená clivisom $g f$ na slabike no. Melódia fragmentu: ma-lig-no fgagaca-agef-gagf. Melódia vzorového kódexu: ma-li-gno fgagaca-aagfeefga-gf. 
Gyrum caeli circuivi (006793 Responsories, č. 6032) je responzórium šiesteho modu. Melódia kopíruje melódiu $B A I$ a pri porovnávaní neboli nájdené žiadne podstatné odchýlky medzi danými melódiami. Obdobným prípadom je aj príslušný verš Ego in altissimis (006793a), ktorý rovnako neobsahuje výraznejšie melodické alebo kompozičné odchýlky od vzorového kódexu.

Verbum iniquum (007841, Responsories, č. 1068) patrí medzi spevy prvého modu. Úvodná čast’ spevu je jasne prebratá z modelu melódií druhého modu. Úvod používa c-klúč na štvrtej linajke notovej osnovy, ten sa v strede slova iniquum na začiatku nového riadku s novou sústavou mení na $f$-klúč umiestnený na tretej linajke notovej osnovy. Melódiu fragmentu sme porovnávali s melódiou BA I. Najvýraznejšie odchýlky boli opät badatel’né najmä v melizmatickejších úsekoch melódie. Dva najväčšie rozdiely v melódii sú na mieste zmeny klúča v slove iniquum a najväčšej melizmatickej časti melódie v slove mihi. Melódia slova iniquum sa od vzorového zápisu odlišuje len jej priebehom, technická stránka zápisu - kompozícia neum - ostáva rovnaká v oboch rukopisoch. Toto neplatí o melódii slova mihi. V tomto prípade sa mierne líši melodický priebeh, aj samotné zloženie použitých neum. Fragment zaznamenáva striedmejšiu melódiu a k tomu prislúchajúce jednoduchšie neumové štruktúry. Melódia vzorového kódexu je bohatšia, viac melizmatická a kompozične komplikovanejšia.

Neumový a melodický zápis fragmentu: mi-hi (pes subbipunctis) gagf (pes) ef - (clivis) fe.

Neumový a melodický zápis vzorového kódexu: mi-hi (bistropha) aa (climacus) gfe (torculus resupinus) $f g f g$ - (clivis) $g f$. Ostatné časti spevu kopírujú melodický priebeh vzorového fragmentu.

Tabulka č. 3: MMTN - Kn/I-13, Historia Sapientiae

\begin{tabular}{|l|l|l|l|l|}
\hline & $\begin{array}{l}\text { MMTN - Kn/I-13, } \\
\text { Historia Sapientiae }\end{array}$ & Pražský rítus & Ostrihomský rítus & $\begin{array}{l}\text { Klosterneuburg, A-KN } \\
1012\end{array}$ \\
\hline R3 & $\begin{array}{l}\text { Domine Pater et Deus, } \\
006503\end{array}$ & $\begin{array}{l}\text { Domine Pater et } \\
\text { Deus }\end{array}$ & $\begin{array}{l}\text { Domine Pater et } \\
\text { Deus }\end{array}$ & $\begin{array}{l}\text { Da mihi domine sedium } \\
\text { tuarum }\end{array}$ \\
\hline V3 & $\begin{array}{l}\text { Da mihi Domine sedium, } \\
006503 a\end{array}$ & $\begin{array}{l}\text { Da mihi Domine } \\
\text { sedium }\end{array}$ & $\begin{array}{l}\text { Da mihi Domine } \\
\text { vomitae pater et deus }\end{array}$ \\
\hline R4 & $\begin{array}{l}\text { Da mihi Domine sedium, } \\
006387\end{array}$ & $\begin{array}{l}\text { Da mihi Domine } \\
\text { sedium }\end{array}$ & $\begin{array}{l}\text { Da mihi Domine } \\
\text { sedium }\end{array}$ & $\begin{array}{l}\text { Domine pater et deus } \\
\text { vitae }\end{array}$ \\
\hline V4 & $\begin{array}{l}\text { Domine Pater et Deus, } \\
006387 a\end{array}$ & $\begin{array}{l}\text { Domine Pater et } \\
\text { Deus }\end{array}$ & $\begin{array}{l}\text { Domine Pater et } \\
\text { Deus }\end{array}$ & Da mihi domine \\
\hline R5 & $\begin{array}{l}\text { Gyrum caeli circuivi, } \\
006793\end{array}$ & $\begin{array}{l}\text { Gyrum caeli } \\
\text { circuivi }\end{array}$ & $\begin{array}{l}\text { Gyrum caeli } \\
\text { circuivi }\end{array}$ & $\begin{array}{l}\text { Gyrum caeli circuivi } \\
\text { sola et }\end{array}$ \\
\hline V5 & Ego in altissimis, 006793a & Ego in altissimis & Ego in altissimis & Ego in altissimis \\
\hline R6 & $\begin{array}{l}\text { Initium sapientiae, 00696 } \\
\text { Initium sapientiae }\end{array}$ & Initium sapientiae & $\begin{array}{l}\text { Initium sapientiae timor } \\
\text { domini intellectus }\end{array}$ \\
\hline V6 & $\begin{array}{l}\text { Dispersit dedit } \\
\text { pauperibus, 006967a }\end{array}$ & $\begin{array}{l}\text { Dispersit dedit } \\
\text { pauperi- }\end{array}$ & $\begin{array}{l}\text { Dispersit dedit } \\
\text { pauperi- }\end{array}$ & $\begin{array}{l}\text { Dispersit dedit } \\
\text { pauperibus justitia ejus }\end{array}$ \\
\hline R7 & Verbum iniquum, 007841 & Verbum iniquum & Verbum iniquum & $\begin{array}{l}\text { Verbum iniquum et } \\
\text { dolosum longe }\end{array}$ \\
\hline V7 & Ne forte satiatus, 007841a & Ne forte satiatus & Ne forte satiatus & Ne forte satiatus \\
\hline
\end{tabular}




\section{MMTN - Kn/I-15}

Antifonár MMTN - Kn/I-15 dokumentuje 14 spevov pôstneho obdobia sviatku Bielej soboty (Sabbato Sancto, matutínum: druhé a tretie nokturno a ranné chvály). Obsahovú zhodu pripisujeme hlavne tomu, že dané časti v rámci sviatkov Vel'kej noci neboli takmer vôbec variabilné, čo dokazuje aj porovnanie fragmentu s ostatnými liturgickými poriadkami. Fragment obsahuje 13 spevov: dva spevy druhého nokturna: responzórium a príslušný verš; devät spevov tretieho nokturna: tri antifóny, tri responzóriá a tri antifóny na ranné chvály. Z daných spevov sa zachovala melódia len v prípade spevov In pace factus est, Deus adjuvat me, Aestimatus sum cum, Et sicut vulnerati a troch antifón $O$ mors ero mors, Plangent eum quasi a Attendite universi. Verš In pace factus est (006605a, Responsories 4066) je v štvrtom mode a melodicky kopíruje melódiu vzorového kódexu Bratislavského antifonára III, v ktorej sa nenachádzajú odchýlky od melódie porovnávaného fragmentu. Zhodu melódie so vzorovým kódexom MMMA nachádzame aj pri porovnaní melódie antifóny Deus adjuvat me (002165).

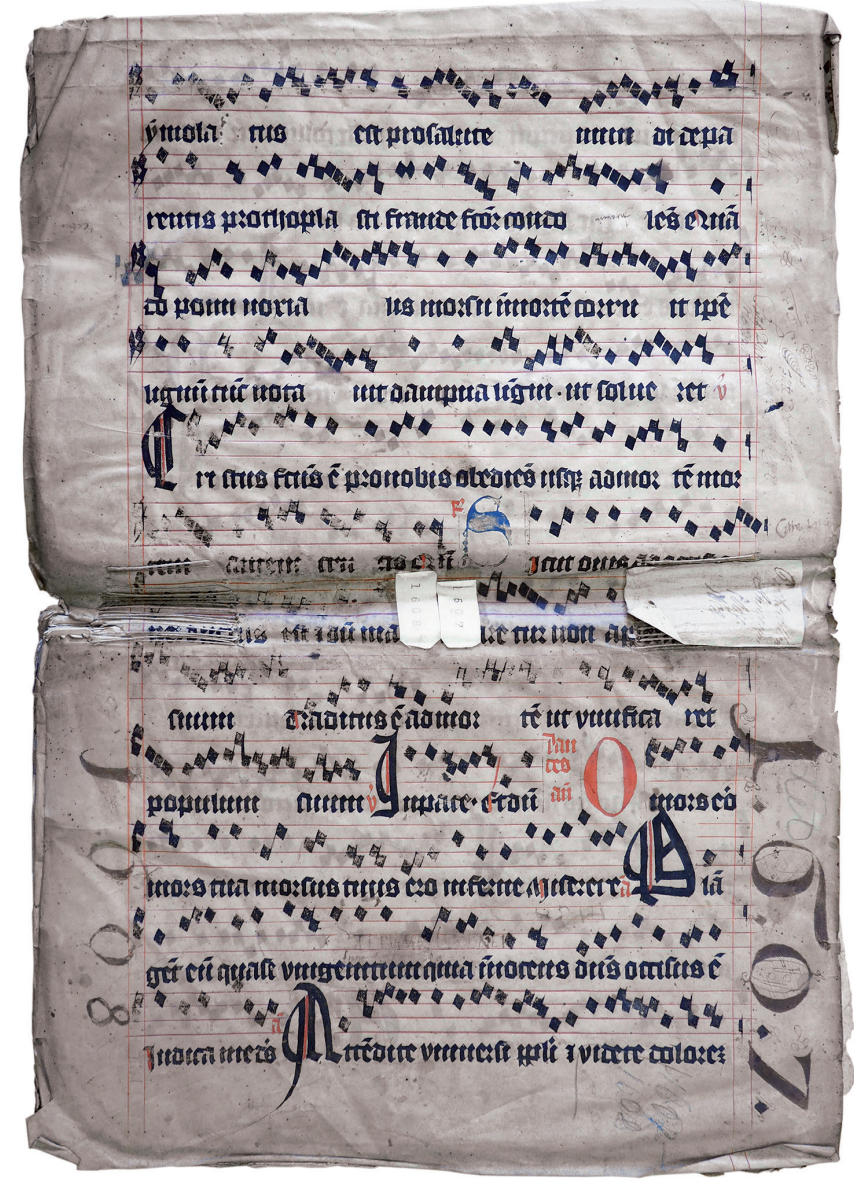

Obr. 6: Antifonár SK-TN MMTN-Kn/I-15, f.1v, Štátny archív Trenčín 
Antifóna patrí do skupiny spevov ôsmeho modu, ktoré tvoria najbohatšiu čast’ celého stredovekého repertoáru antifón. Antifóny ôsmeho modu sú členené do jasného systému príbuzných typov a podtypov, pričom niektoré časti spevov sa v rámci modu úzko vztahujú $\mathrm{k}$ archaickým skupinám $\mathrm{z}$ obdobia pred zavedením systému ôsmich modov. ${ }^{53}$ Jediný rozdiel v melódii danej antifóny nachádzame na konci spevu, v mieste susceptor est. Melódia vzorového kódexu: sus-ce-ptor est h-a-c ha. Melódia skúmaného fragmentu: sus-ce-ptor est: $h$-a-h-ca. Zlomok obsahuje aj responzórium Aestimatus sum cum (006057) s veršom Et sicut vulnerati (006057a - MMMA 4), ktoré sú spevmi štvrtého modu a ich melódia je totožná s melódiou vzorového kódexu MMMA - Bratislavského antifonára III. Melódia prvej frázy responzória je totožná so vzorovou melódiou spevov štvrtého modu, ktorá sa používala v miestach vplyvu ostrihomskej tradície. Melódia sa začína na tóne $f$, podporená tónom $d$ na druhej slabike. Slabiky $1-3$ tak určujú melodický incipit, bez ohladu na zdôraznenie týchto slabík. Nasleduje recitácia na tónoch $f$ zakončená krátkou melizmou končiacou $d$ kadenciou na poslednej slabike. Tóny zakončujúce melizmu majú stanovené poradie a správajú sa ako fixná formula (často s $e$ namiesto $f$ vo františkánskej tradícii), $f$ recitácia môže byt’ kratšia alebo dlhšia na základe počtu slabík v danej fráze. ${ }^{54}$ Antifóna $O$ mors ero mors (004045) a antifóna Plangent eum quasia (004295) sú antifónami štvrtého modu. V oboch prípadoch je melodický zápis antifón oproti vzorovej melódii transponovaný o kvartu vyššie. Melódia oboch spevov verne kopíruje priebeh melódie vzorového kódexu. Antifóna Attendite universi (001512, MMMA 7038) je antifónou siedmeho modu. Melódia danej antifóny je zhodná s melodickým zápisom vzorového kódexu MMMA Bratislavského antifonára III.

Tabulka č. 4: MMTN - Kn/I-15, Sabbato Sancto

\begin{tabular}{|l|l|l|l|l|}
\hline & $\begin{array}{l}\text { MMTN - Kn/I-15, } \\
\text { Sabbato Sancto }\end{array}$ & Pražský rítus & $\begin{array}{l}\text { Ostrihomský } \\
\text { rítus }\end{array}$ & $\begin{array}{l}\text { Klosterneuburg, A-KN } \\
\mathbf{1 0 1 7}\end{array}$ \\
\hline R3 & $\begin{array}{l}\text { Ecce quomodo moritur, } \\
006605\end{array}$ & $\begin{array}{l}\text { Ecce quomodo } \\
\text { moritur }\end{array}$ & $\begin{array}{l}\text { Ecce quomodo } \\
\text { moritur }\end{array}$ & $\begin{array}{l}\text { Ecce quomodo moritur } \\
\text { justus }\end{array}$ \\
\hline V3 & In pace factus est, 006605a & In pace factus est & In pace factus est & In pace factus est locus ejus \\
\hline A1 & Deus adjuvat me, 002165 & Deus adjuvat me & Deus adjuvat me & Deus adjuvat me et dominus \\
\hline A2 & In pace factus est, 003264 & In pace in idipsum & In pace factus est & In pace factus est locus \\
\hline A3 & Factus sum sicut, 002849 & Factus sum sicut & Factus sum sicut & Factus sum sicut homo sine \\
\hline R1 & $\begin{array}{l}\text { Aestimatus sum cum, } \\
006057\end{array}$ & $\begin{array}{l}\text { Aestimatus sum } \\
\text { cum }\end{array}$ & $\begin{array}{l}\text { Aestimatus sum } \\
\text { cum }\end{array}$ & Aestimatus sum cum \\
\hline V1 & Et sicut vulnerati, 006057a & Et sicut vulnerati & Et sicut vulnerati & Et sicut vulnerati dormientes \\
\hline R2 & $\begin{array}{l}\text { Agnus Dei Christus, } \\
006065\end{array}$ & $\begin{array}{l}\text { Agnus Dei } \\
\text { Christus }\end{array}$ & $\begin{array}{l}\text { Agnus Dei } \\
\text { Christus }\end{array}$ & $\begin{array}{l}\text { Agnus dei Christus } \\
\text { immolatus }\end{array}$ \\
\hline V2 & Christus factus est, 006065a & Christus factus est & Christus factus est & Christus factus est pro nobis \\
\hline R3 & $\begin{array}{l}\text { Sicut ovis ad occisionem, } \\
007661\end{array}$ & $\begin{array}{l}\text { Sicut ovis ad } \\
\text { occisionem }\end{array}$ & $\begin{array}{l}\text { Sicut ovis ad } \\
\text { occisionem }\end{array}$ & Sicut ovis ad occisionem \\
\hline V3 & In pace factus est, 007661a & In pace factus est & In pace factus est & In pace factus est locus ejus \\
\hline A1 & O mors ero mors, 04045 & O mors ero mors & O mors ero mors & O mors ero mors tua morsus \\
\hline A2 & $\begin{array}{l}\text { Plangent eum quasi, } \\
004295\end{array}$ & $\begin{array}{l}\text { Plangent eum } \\
\text { quasi }\end{array}$ & $\begin{array}{l}\text { Plangent eum } \\
\text { quasi }\end{array}$ & $\begin{array}{l}\text { Plangent eum quasi } \\
\text { unigenitum }\end{array}$ \\
\hline A3 & Attendite universi, 001512 & Attendite universi & Attendite universi & Attendite universi populi et \\
\hline
\end{tabular}

53 DOBSZAY - SZENDREI, Antiphonen, Ref. 39, s. 98.

54 DOBSZAY - SZENDREI, Responsories, Ref. 39, s. 107. 


\section{MMTN - Kn/I-18}

Fragment $M M T N$ - Kn/I-18 obsahuje spevy druhého a tretieho nokturna sviatku Conceptio Mariae. V rámci fragmentu sa zachovalo 7 spevov: Patriarcharum semine (601757), Nobilis et clara stirps (601757a), Verbum patris mundo (602429), Solem justitiae (602429a), Rubus quondam incombustus (512080320), Haec fratrum magnum (512080330), Prima spernens viri (512080340). Kompletne sa zachovali 4 spevy: Nobilis et clara stirps (601757a), Verbum patris mundo (602429), Rubus quondam incombustus (5.1208.0330) a Haec fratrum magnum (5.1208.0330).

Po porovnaní liturgického obsahu fragmentu sme určili úplnú zhodu s českým liturgickým poriadkom. Ostrihomský poriadok a poriadok liturgického kódexu $A-K N$ 1017 nevykazujú s poriadkom fragmentu ani najmenšiu obsahovú zhodu. Ostrihomský rítus pracuje so spevmi Prophetalis nubem, Diffugiunt tenebrae, Celebris dies colitur, Ista fuit digna, Abrahae fit promissio, Hoc promissum est, Vinea quondam sterilis. Liturgický poriadok A-KN 1017 so spevmi Virga Jesse de radice genus, Voce prophetiae signatur, Prophetalis nubem levem vox, Diffugiunt tenebrae pandunt, Abrahae fit promissio quod, Hoc promissum est impletum, Gratulare et laetare urbs. Kedže vyššie uvedené celkovo zachované spevy nie sú zahrnuté ani v publikácii Responsories, ani MMMA, melódie zachovaných spevov fragmentu sme porovnávali s melódiami z databázy Cantus Index a z národnej databázy Slovak Early Music Database (SEMD). Prvý zachovaný spev V2.2 Nobilis et clara stirps (601757a) sa v databáze SEMD nevyskytuje $\mathrm{v}$ rámci žiadneho uceleného kódexu. Čast’ spevu dokumentuje fragment Varadínskeho antifonára Manus. $148 .{ }^{55}$ Spev nachádzame v rámci kódexu A-KN 1017. Z dôvodu absencie digitálnej verzie kódexu sme v tomto prípade pracovali s kódexom $A-K N$ 1012. ${ }^{56}$ Melódia fragmentu sa však nezhoduje s melódiou kódexu, ani priebehom, ani umiestnením klúča. Melódia fragmentu má vo viacerých častiach opačný priebeh ako melódia kódexu. Rovnako sa melódia nezhoduje ani približne so žiadnou z melódií uverejnených v databáze Cantus Index. Obdobný prípad je aj responzórium Verbum patris mundo (602429). Spev sa vyskytuje v liturgickom poriadku $A-K N$ 1017, porovnávali sme ho s melódiou $A-K N$ 1012. Melódia spevu fragmentu sa nezhoduje ani s melódiou kódexu, ani so žiadnou inou melódiou databázy. Zachované antifóny $R u$ bus quondam incombustus (5.1208.0330) a Haec fratrum magnum (5.1208.0330) nebolo možné porovnat’ so žiadnym prameňom $\mathrm{z}$ dôvodu absencie melódií týchto spevov v rámci databázy Cantus Index či databázy Hungarian Chant Database. ${ }^{57}$ Existenciu a poradie spevov sme overili v rámci liturgických poriadkov CAO-ECE, ktoré pracujú výhradne s incipitmi spevov bez melodického zápisu.

55 VESELOVSKÁ - ADAMKO - BEDNÁRIKOVÁ, Ref. 30, s. 233; Dostupné online: <http://cantus. sk/source/13894>.

56 Dostupné online: $<$ https://manuscripta.at/diglit/AT5000-1012/0001>.

57 Spev Rubus quondam incombustus je evidovaný $\mathrm{v}$ rámci madarskej databázy http://hun-chant. eu/ pod číslom 512080320 a rovnako je uvedený v rámci pražského liturgického poriadku CAO-ECE III/B. Melódia, ako aj celý text spevu sú dostupné len v liturgickom kódexe Breviarium Pragense - VII A 12, Národní knihovna České republiky, ktorý doposial nie je prístupný v digitálnej podobe $\mathrm{v}$ žiadnej z dosiahnutelných databáz. 
Tabulka č. 5: MMTN - Kn/I - 18, Conceptio Mariae

\begin{tabular}{|l|l|l|l|l|}
\hline & $\begin{array}{l}\text { MMTN - Kn/I - 18 } \\
\text { Conceptio Mariae }\end{array}$ & Pražský rítus & Ostrihomský rítus & $\begin{array}{l}\text { Klosterneuburg, A-KN } \\
1017\end{array}$ \\
\hline R2 & $\begin{array}{l}\text { Patriarcharum semine, } \\
601757\end{array}$ & $\begin{array}{l}\text { Patriarcharum } \\
\text { semine }\end{array}$ & Prophetalis nubem & $\begin{array}{l}\text { Patriarcharum semine } \\
\text { prophetarum origine regum }\end{array}$ \\
\hline V2 & $\begin{array}{l}\text { Nobilis et clara stirps } \\
601757 a\end{array}$ & $\begin{array}{l}\text { Nobilis et clara } \\
\text { stirps }\end{array}$ & $\begin{array}{l}\text { Diffugiunt } \\
\text { tenebrae }\end{array}$ & Nobilis et clara stirps est \\
\hline R3 & $\begin{array}{l}\text { Verbum patris mundo, } \\
602429\end{array}$ & $\begin{array}{l}\text { Verbum patris } \\
\text { mundo }\end{array}$ & $\begin{array}{l}\text { Celebris dies } \\
\text { colitur }\end{array}$ & XXX \\
\hline V3 & Solem justitiae, 602429a & Solem justitiae & Ista fuit digna & XXX \\
\hline A1 & $\begin{array}{l}\text { Rubus quondam } \\
\text { incombustus, } \\
5.1208 .0320\end{array}$ & $\begin{array}{l}\text { Rubus quondam } \\
\text { incombustus }\end{array}$ & $\begin{array}{l}\text { Abrahae fit } \\
\text { promissio }\end{array}$ & $\begin{array}{l}\text { Conceptus hodiernus } \\
\text { Mariae semper virginis }\end{array}$ \\
\hline A2 & $\begin{array}{l}\text { Haec fratrum magnum, } \\
5.1208 .0330\end{array}$ & $\begin{array}{l}\text { Haec fratrum } \\
\text { magnum }\end{array}$ & Hoc promissum est & $\begin{array}{l}\text { Gloriosa semper virgo Maria } \\
\text { dulcissima }\end{array}$ \\
\hline A3 & $\begin{array}{l}\text { Prima spernens viri, } \\
5.1208 .0340\end{array}$ & Prima spernens viri & $\begin{array}{l}\text { Vinea quondam } \\
\text { sterilis }\end{array}$ & $\begin{array}{l}\text { Maria plena gratia stirpe } \\
\text { concepta }\end{array}$ \\
\hline
\end{tabular}

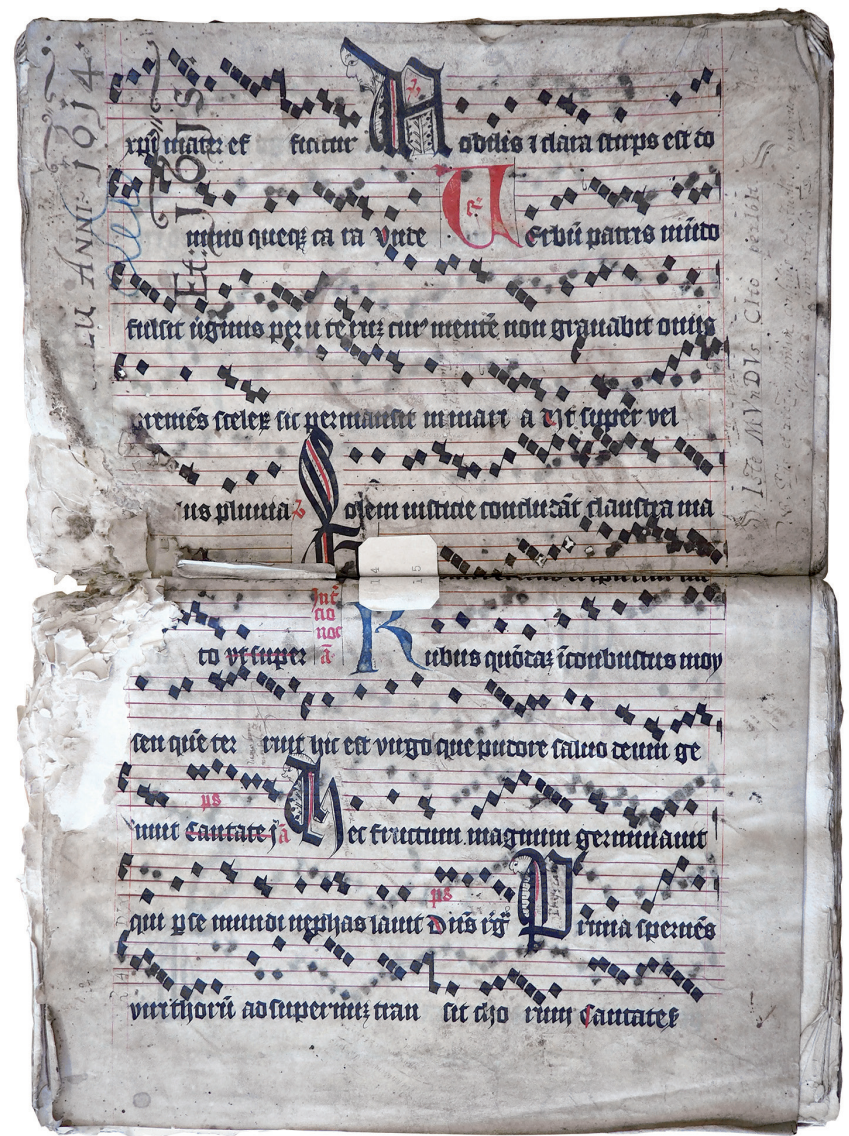

Obr. 7: Antifonár SK-TN MMTN-Kn/I-18, Štátny archív Trenčín 


\section{MMTN - Kn/I-27}

Fragment antifonára $M M T N$ - Kn/I-27 dokumentuje vešpery a prvé nokturno sviatku sv. Mikuláša (s. Nicolao) a tretie nokturno sviatku Dominica I Quadragesimae časti Proprium de tempore. Celkovo sa v rámci fragmentu dochovalo 13 spevov Beatus Nicolaus jam (006222), Ut apud Christum (006222a), Gloria patri et filio (007040b), O pastor aeterne (004051), Confessorum regem adoremus (001056), Nobilissimis siquidem (003888), Postquam domi puerilem (004336), Pudore bono repletus (004408), Confessor Dei Nicolaus (006310), Erat enim valde compatiens (006310a), Operibus sanctis Nicolao (007324), Voce quippe de caelo (007324a), Et cum jejunasset (006520a), z toho 6 kompletne. Pri porovnaní liturgického obsahu kódexu s českým, ostrihomským liturgickým poriadkom a poriadkom kódexu $A-K N 1011$ sme až na obsah jedného spevu zistili absolútnu zhodu so všetkými porovnávanými liturgickými poriadkami. Komparácia fragmentu s poriadkom A-KN 1017 nepreukázala v danej časti liturgie hodín zhodu s liturgickým poriadkom kódexu. Po melodickej stránke sa Ut apud Christum (006222a, Responsories 6055) s melódiou vzorového kódexu nezhoduje. Okrem klúča a transpozície nie je zhodný ani priebeh melódie. Naopak, Gloria patri et filio sa melodicky až na zanedbatel'né odchýlky s melódiou vzorového kódexu zhoduje. Melódie antifón Nobilissimis siquidem (003888, MMMA 1503) a Pudore bono repletus (004408) sú zhodné s melódiou kódexu MMMA. Poslednými spevmi fragmentu sú Operibus sanctis Nicolao (007324, Responsories 2117) a Voce quippe de caelo (007324a). Rovnako ako v prípade antifón sa aj napriek malým odchýlkam melódia kódexu zhoduje s melódiou vzorového kódexu Responsories.

Tabulka č. 6: MMTN - Kn/I-27, Dominica I Quadragesimae, Proprium de tempore

\begin{tabular}{|l|l|l|l|l|}
\hline & $\begin{array}{l}\text { MMTN - Kn/I-27, } \\
\text { Dominica } \\
\text { I Quadragesimae, } \\
\text { Proprium de tempore }\end{array}$ & Pražský rítus & Ostrihomský rítus & $\begin{array}{l}\text { Klosterneuburg, A-KN } \\
1011\end{array}$ \\
\hline R & $\begin{array}{l}\text { Beatus Nicolaus jam } \\
\text { tri- }\end{array}$ & $\begin{array}{l}\text { Beatus Nicolaus jam } \\
\text { tri- }\end{array}$ & $\begin{array}{l}\text { Beatus Nicolaus jam } \\
\text { trium }\end{array}$ & Beatus Nicolaus* $^{*}$ \\
\hline V & Ut apud Christum & Ut apud Christum & Ut apud Christum & XXX \\
\hline H & xxx & Plaudat laetitia & Exsultet aula caelica & Plaudat laetitia \\
\hline W & Gloria patri et filiio & Ecce sacerdos & Amavit eum Dominus & XXX \\
\hline Am & O pastor aeterne & O pastor aeterne & O pastor aeterne & O pastor aeterne \\
\hline a & $\begin{array}{l}\text { Confessorum regem } \\
\text { adore- }\end{array}$ & $\begin{array}{l}\text { Confessorum regem } \\
\text { adore- }\end{array}$ & $\begin{array}{l}\text { Confessorum regem } \\
\text { adoremu }\end{array}$ & $\begin{array}{l}\text { Confessorum regem } \\
\text { adoremus }\end{array}$ \\
\hline H & xxx & Plaudat laetitia (div.) & xxx & Christe salvator \\
\hline a1 & $\begin{array}{l}\text { Nobilissimus } \\
\text { siquidem }\end{array}$ & $\begin{array}{l}\text { Nobilissimus } \\
\text { siquidem }\end{array}$ & $\begin{array}{l}\text { Nobilissimus } \\
\text { siquidem }\end{array}$ & Nobilissimis siquidem \\
\hline a2 & $\begin{array}{l}\text { Postquam domi } \\
\text { puerilem }\end{array}$ & $\begin{array}{l}\text { Postquam domi } \\
\text { puerilem }\end{array}$ & $\begin{array}{l}\text { Postquam domi } \\
\text { puerilem }\end{array}$ & Postquam domi puerilem \\
\hline a3 & Pudore bono repletus & Pudore bono repletus & Pudore bono repletus & Pudore bono repletus dei \\
\hline W & xxx & Ecce sacerdos & Amavit eum Dominus & Confessor dei Nicolaus \\
\hline R1 & $\begin{array}{l}\text { Confessor Dei } \\
\text { Nicolaus }\end{array}$ & $\begin{array}{l}\text { Confessor Dei } \\
\text { Nicolaus }\end{array}$ & $\begin{array}{l}\text { Confessor Dei } \\
\text { Nicolaus }\end{array}$ & $\begin{array}{l}\text { Erat enim valde } \\
\text { compatiens et }\end{array}$ \\
\hline V1 & $\begin{array}{l}\text { Erat enim valde } \\
\text { compati- }\end{array}$ & $\begin{array}{l}\text { Erat enim valde } \\
\text { compati- }\end{array}$ & $\begin{array}{l}\text { Erat enim valde } \\
\text { compatien }\end{array}$ & Operibus sanctis Nicolao \\
\hline R2 & Operibus sanctis & Operibus sanctis & Operibus sanctis & Voce quippe de caelo lapsa \\
\hline V2 & Voce quippe de caelo & Voce quippe de caelo & Voce quippe de caelo & Quadam die tempestate \\
\hline
\end{tabular}




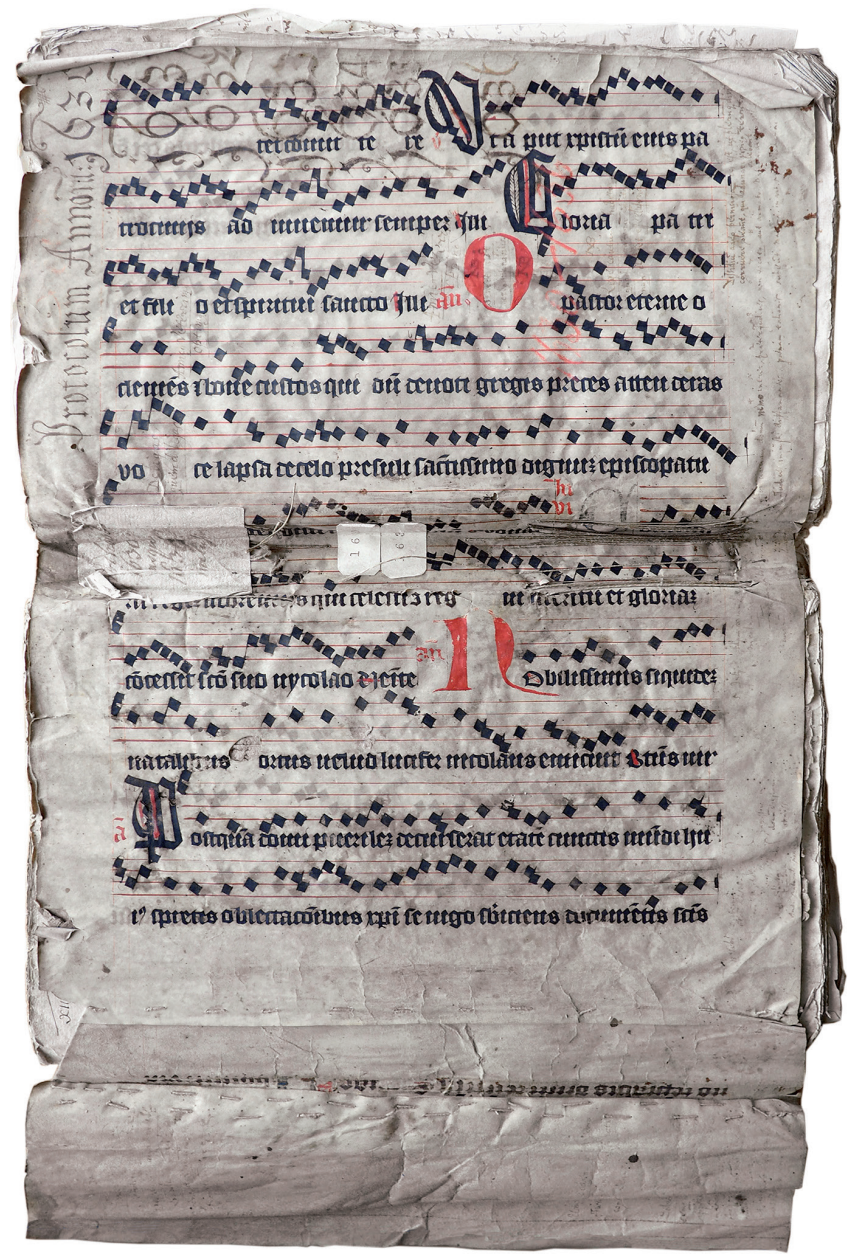

Obr. 8: Antifonár SK-TN MMTN-Kn/I-27, f.1r, Štátny archív Trenčín

\section{Záver}

Fragmenty Štátneho archívu Trenčín sú súčastou jedinečného obrazu stredovekej hudobnej kultúry z územia Slovenska a úzko korešpondujú so skriptorskou tradíciou Moravy (Olomoucké skriptórium).

$\mathrm{Na}$ základe historických súvislostí sme od začiatku výskumu predpokladali, že rukopisy notované českou notáciou mohli pochádzat’ z územia dnešného Slovenska a viazat’ sa $\mathrm{k}$ rádu augustiniánov, ktorí pôsobili v Novom Meste nad Váhom, prípadne $\mathrm{k}$ územiu dnešného Považia. Vzhl’adom na charakter notácie a obsahovo-melodickú komparáciu sa prikláňame k názoru, že dané zlomky sú úzko prepojené s územím dnešnej Moravy. Tomuto tvrdeniu napovedá aj fakt, že k podskupine fragmentov antifonára môžeme priradit aj fragment Antifonára sign. 
MSBaFrPrus 25376 (2 ff.) zo Slovenskej národnej knižnice. ${ }^{58}$ Vzhladom na zhodu kodikologicko-paleografických parametrov uvedeného fragmentu a podskupiny zlomkov antifonára „A“ je možné tvrdit’, že všetky zmienené zlomky pochádzajú z rovnakého liturgického kódexu. Notácia daných zlomkov sa približuje notácii rukopisov moravského okruhu, najmä rukopisom Graduálu FM 2, ${ }^{59}$ Antifonára FM $5^{60}$ a rukopisom Knihovny Metropolitní kapituly svatého Václava v Olomouci. ${ }^{61}$ Obsahovo je tažké jednoznačne určit', ktorý liturgický poriadok fragmenty dokumentujú. S najväčšou pravdepodobnostou boli zlomky zhotovené českým, resp. moravským notátorom (či už na území dnešného Slovenska, alebo Čiech). Pôvod predlohy, podla ktorej bol kódex vyhotovený, ostáva otázny - smeruje však k pražskej, resp. augustiniánskej liturgickej tradícii.

Z obsahového hladiska by sme chceli upozornit' na dva fragmenty. Antifonár MMTN-Kn/I-11 obsahuje spevy Iratus rex Saul a Quis enim in omnibus sicut, ktoré dokladajú možný súvis $s$ rádom augustiniánov. Spomínané spevy neboli bežným repertoárom pražského ani ostrihomského rítu. Objavujú sa najmä v kódexoch, ktoré pochádzajú z augustiniánskeho kláštora v Klosterneuburgu. Svojím obsahom je zaujímavý i Antifonár MMTN - Kn/I-18. Zlomok dokumentuje spevy nokturna sviatku Conceptio Mariae, ${ }^{62}$ ktoré sú v rukopisoch slovenskej a českej proveniencie vzácne. Spevy Nobilis et clara stirps a Verbum patris mundo obsahujú napríklad kódexy kláštora v Klosterneuburgu. Melódia spevov však nie je zhodná s klosterneburskými kódexami. Raritné sú spevy Rubus quondam incombustus a Haec fratrum magnum, ktorých melódia sa neobjavuje v žiadnej z dostupných databáz. ${ }^{63}$

58 LAZORÍK, Eduard: Stredoveké rukopisné fragmenty na tlačiach 16. storočia z fondu františkánskych knižníc Slovenskej národnej knižnice. Martin : Slovenská národná knižnica, Odbor správy a spracovania HKD a HKF, 2019, s. 29.

59 Moravský zemský archiv, fond G 11, FM 2, Graduál.

60 Moravský zemský archiv, fond G 11, FM 5, Antifonár.

${ }_{61}$ ČERVENKA, Stanislav: Středověké chorální rukopisy moravských a slezských sbírek a jejich muzikologická exploatace - současný stav a prespektivy. In: BUREŠOVÁ, Alena (ed.): Kritické edice hudebních památek. Olomouc : Univerzita Palackého v Olomouci, 1996, s. 39-44; POKORNÝ, Fratišek - ČERVENKA, Stanislav: Nepublikované studie Františka Pokorného. Brno : Moravská zemská knihovna v Brně, 2018; ZACHOVÁ, Irena - STANISLAV, Petr: Soupis sbírky rukopisů bývalého Františkova muzea v Brně. Brno : Masarykův ústav AV ČR, 2011.

62 Ofícium Ave decus virgineum v edícii CAO-ECE III/B uvádza iba v dvoch liturgických kódexoch: v Pražskom breviári VII A 12 (Národní knihovna České republiky) a v Antifonári z Hradca Králové, II A 4 (Muzeum Východních Čech). Rovnaké spevy ako v trenčianskom fragmente sa ale nachádzajú iba v Pražskom breviári VII A 12. Textovú podobnost’ so spevom Rubus quondam incombustus nachádzame v antifóne Namque rubus incombustus Moyses, ktorá sa v rámci ofícia Ave decus virgineum vyskytuje $v$ Antifonári Hradca Králové II A 4 a je i súčastou kódexov z Klosterneuburgu A-KN 1010 a A-KN 1017.

63 Spev Rubus quondam incombustus je evidovanýv rámci mad’arskej databázy http://hun-chant.eu/ pod číslom 512080320, a rovnako je uvedený v rámci ideálneho pražského liturgického poriadku v edícii CAO-ECE III/B. 

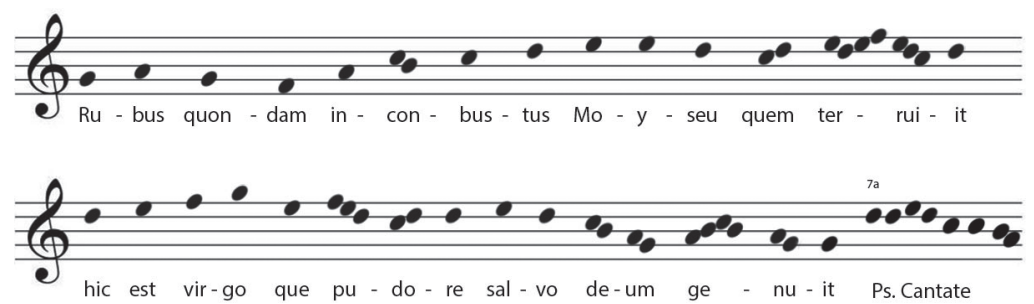

Obr. 9: Kompletná melódia antifóny Rubus quondam fragmentu MMTN - Kn/I-18, Protocollum Civitatis Trenchiniensis anni $1614-1615$
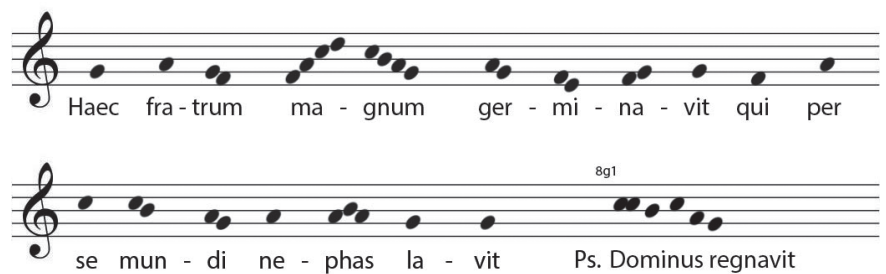

Obr. 10: Kompletná melódia antifóny Haec fratrum fragmentu $M M T N-K n / I-18$, Protocollum Civitatis Trenchiniensis anni 1614 - 1615

Štúdia je súčastou grantového projektu APVV-19-0043 „CANTUS PLANUS na Slovensku: lokálne prvky - transregionálne vztahy“" $(2020$ - 2024), riešeného v Ústave hudobnej vedy SAV a projektu Mobility Slovenskej akadémie vied: Hudobná kultúra strednej Európy 1450 - 1650: transregionálna identita hudobných prameňov z Klosterneubuergu a Bratislavy (2020 - 2022). 


\section{Summary}

\section{The Medieval Office Repertoire in the Notated Fragments of the State ArChives in Trenčín}

The notated fragments deposited in the State Archives in Trenčín form pieces of a unique picture of medieval musical culture from the territory of Slovakia and closely correspond to the Moravian scribal tradition (the scriptorium of the Metropolitan Chapter of Saint Wenceslas in Olomouc). From the total number of twenty-two notated medieval fragments situated in Trenčín mainly in bindings of official municipal books from the sixteenth and the seventeenth centuries, sixteen fragments are notated in Bohemian notation. From this group of materials, we selected a group with specific contents. We carried out an in-depth musical liturgical analysis of the medieval office repertoire recorded in the selected fragments (so-called Antiphonary "A"), identified to have belonged to a single liturgical codex which has unfortunately not survived in its entirety.

At the beginning of our research, based on the historical contexts we assumed that the manuscripts notated with Bohemian notation might have come from the territory of present-day Slovakia and might have been linked to the Augustinians, who were active in Nové Mesto nad Váhom, or to the region of the Váh river. In view of the character of the notation and based on contentual and melodic comparisons, we are now inclined to believe that the birth of these fragments is linked to the territory of present-day Moravia, namely to the scriptorium of the Metropolitan Chapter of Saint Wenceslas in Olomouc. Due to the agreement of its codicological palaeographic parameters with the Trenčín subgroup of fragments of Antiphonary "A", a fragment of Antiphonary MSBaFrPrus 25376 (2 ff.) from the Slovak National Library may also be ranked among this subgroup. The notation of these fragments is close to that of the manuscripts of the Moravian circle, especially of Gradual FM 2 (Moravian Regional Archives, Collection G 11), Antiphonary FM 5 (Moravian Regional Archives, Collection G 11), and the manuscripts of the Library of the Metropolitan Chapter of Saint Wenceslas in Olomouc. From their contents, it is hard to clearly define which liturgical order they document. Most probably the fragments were produced by a Bohemian or, rather, Moravian notator (the manuscript might have been written in the territory of Moravia or copied by a travelling scribe in the territory of present-day Slovakia). The question of the origin of the model after which the codex was created remains open - it appears to point to the Prague or the Augustinian liturgical tradition.

In terms of their contents, two fragments are remarkable. Antiphonary MMTN-Kn/I-11 contains the chants Iratus rex Saul and Quis enim in omnibus sicut, which document possible links to the Order of Saint Augustine. These chants did not form part of the regular repertoire of the Prague or the Esztergom rite. They figure mainly in codices that originated in the Augustinian monastery in Klosterneuburg. The contents of Antiphonary MMTN - Kn/I-18 are also intriguing. This fragment documents chants of the nocturns of the feast of Conceptio Mariae that are very rare in manuscripts of Slovak or Bohemian provenance. The chants Nobilis et clara stirps and Verbum patris mundo figure e.g. in codices of the Augustinian monastery in Klosterneuburg. The melody of the chants, however, does not correspond to the Klosterneuburg codices. The chants Rubus quondam incombustus and Haec fratrum magnum, whose melodies do not appear in any of the available databases, are also rarities. 